\title{
Culture and Food Security
}

\author{
Elena Briones Alonso ${ }^{a, 1}$, Lara Cockx ${ }^{a}$, Johan Swinnen ${ }^{a, b}$ \\ ${ }^{a}$ LICOS - Centre for Institutions and Economic Performance, KU Leuven, Leuven, Belgium \\ ${ }^{\mathrm{b}}$ CEPS - Centre for European Policy Studies, Brussels, Belgium
}

\begin{abstract}
This paper reviews available cross-disciplinary evidence on how culture affects food security. We discuss the impact of culture on all four dimensions (availability, access and choice, utilization, and stability). There is large heterogeneity in the size and breadth of available evidence, with research often biased toward high-come countries. The dynamics as well as the magnitude and relative importance of cultural effects on food security are still poorly understood. Despite these gaps in the literature, it is clear that how and why we obtain, process, prepare, and eat food is influenced by culture in various ways. Gender, family, and decision-making power play a critical role in interacting with culture and its impact on food security. There remains ample scope for improving food security policy by taking culture better into account.
\end{abstract}

Keywords: Culture; Food security; Nutrition

\footnotetext{
${ }^{1}$ Corresponding author: 1ara.cockx@kuleuven.be
}

This research was supported by the European Union's Seventh Framework programme FP7 under Grant Agreement n²90693 FOODSECURE - Exploring the Future of Global Food and Nutrition Security. The views expressed are the sole responsibility of the authors.

We are grateful for valuable comments from the anonymous reviewers and workshop participants within the FOODSECURE programme, as well as participants of the 2016 ASREC Conference in Copenhagen. 


\section{Introduction}

Food is intimately related to human culture (e.g. Feeley-Harnik, 1995; Fieldhouse, 1995; Kittler et al., 2011; Mintz and Du Bois, 2002). Improving our understanding of the cultural dimension of food security is therefore increasingly recognized as an essential part of moving towards sustainable healthier diets for all (e.g. Helman, 2007; Keding et al., 2013). This evolution is reflected in the fact that culture is now commonly mentioned as one of the 'deep drivers' of food security in conceptual frameworks (e.g. WFP, 2012).

Yet, in spite of this growing recognition, culture has too often remained on the fringes of discussions on the fight against malnutrition among policy-makers and researchers. There are many examples of well-intended food security interventions that failed because they did not take cultural settings into account (e.g. UN, 2013). They range from rejected deliveries of culturally inappropriate food aid to disregard for dietary recommendations that conflict with the cultural meaning of certain foods. A typical shortcoming is that the frameworks that identify culture as an important driver rarely clarify through what specific channels it affects food security, nor how important its influence is relative to other factors. Put differently, it has been widely acknowledged that culture matters, but the questions of in what ways and to what extent it matters remain largely unanswered.

To some extent, this lacuna may be related to difficulties in operationalizing and measuring such a comprehensive concept (Alesina and Giuliano, 2015; Guiso et al., 2006). Yet, various disciplines have made significant progress in developing theories, models, and instruments to analyse and measure culture qualitatively and quantitatively. In addition, there is a vast and growing body of literature investigating different aspects of culture in relation to several dimensions and drivers of food security. The problem is therefore not absence of research. The issue may rather be that research is scattered across a wide range of disciplines (from anthropology to biochemistry), research topics (from food processing to media and marketing), and types of research. ${ }^{2}$ This dispersion makes it difficult to take stock of the current state of knowledge regarding the impact of culture on food security.

To our knowledge, this paper will be the first to provide an overview of the available evidence on the impact of culture on food security by bringing together these distinct types of research from a range of different disciplines. Since the body of relevant literature is vast, the first step in this process is to determine the scope of our review. We focus our review on the impact of

\footnotetext{
2 One type of studies reviews the impact of cultural factors on one or a few specific drivers of food security across countries - although the focus is often on high-income countries (e.g. Nestle et al., 1998). Another type of research takes the form of detailed case studies on how culture affects a large number of food security drivers for a particular cultural group (e.g. Gittelsohn et al., 2003). These studies generally take a broad approach in terms of cultural factors considered, but have a limited focus in the sense that they are highly specific to the population under study.
} 
culture on the determinants of dietary intake at the household and individual level ${ }^{3}$ and how the current state of knowledge can inform policy making. Although we have tried to use a broad, interdisciplinary approach to account for the complex and multifaceted nature of both culture and food security, as economists, our discussion relies strongly on language and concepts common in our field.

This paper is structured as follows. Section 2 reviews definitions culture and food security. Section 3 discusses the different pathways through which culture affects food security. Section 4 focuses on the role of gender, family and decision-making power. The dynamic aspects of culture and drivers of change, including the role of mass media and marketing, are explored in Section 5. Section 6 concludes and presents the implications for policy and future research.

\section{Definitions of Culture and Food security}

\subsection{Culture}

In the words of Alesina and Giuliano (2015: 899): "Defining culture is an arduous task". There is no universally accepted definition, and different disciplines have defined this complex construct in numerous ways. While some interpretations focus on the core concepts of values, beliefs and norms, others view culture more broadly as all socially transmitted information. The first approach is common within economics, as is illustrated by the definition used by Gorodnichenko and Roland (2010: 1): "the set of values and beliefs people have about how the world (both nature and society) works as well as the norms of behaviour derived from that set of values". The psychological literature tends to emphasize the role of culture in motivating human behaviour. Matsumoto and Juang (2013: 15) for instance define culture as "a unique meaning and information system, shared by a group and transmitted across generations, that allows the group to meet basic needs of survival, pursue happiness and well-being, and derive meaning from life." Other strands of research, including bio-cultural evolutionary work, stress the informational content of culture. Boyd and Richerson (2004) for instance define culture as "information that people acquire from others by teaching, imitation, and other forms of social learning".

With each approach having its strengths and weaknesses, the question of how to define culture in itself can be the subject of a review paper (e.g. Taras et al., 2009). For the sake of brevity and given the broad and interdisciplinary nature of this review, we therefore refrain from giving a strict definition of culture. Rather, we continue by discussing a number of points that we deem important for clarifying and delineating our understanding of culture.

First, we consider the social transmission of information as a crucial aspect of culture. Specific culture traits such as values, beliefs, and behavioural norms can be thought of as ways of

\footnotetext{
${ }^{3}$ By restricting our attention to the household and individual level, we leave aside macro-level effects such as the impact of aggregate food preferences on food trade patterns.
} 
transmitting information, both within and across generations, about how the world works and what is good and bad, right and wrong, or valuable and invaluable. Such traits and the information embedded therein aggregate into cultural models that explain a certain aspect of life (e.g. pregnancy, infant feeding, and illness) and mediate and regulate associated behaviour (D'Andrade and Strauss, 1992; Fryberg and Markus, 2007). Research on culture and food security often gives importance to a particular type of culturally embedded information that is built on long periods of experimentation, observation, and learning across generations (Becker and Ghimire, 2003; Berkes, 2012; Mazzocchi, 2006). To distinguish this type of information from knowledge acquired through modern scientific methods, various terms are used, such as traditional knowledge, indigenous knowledge and local knowledge, each having its own imperfections. We use the term 'traditional knowledge' throughout the paper to emphasize the process of knowledge building and transmission along a cultural continuity (Berkes, 2012; Mazzocchi, 2006).

A second important aspect of culture is its dynamic nature. Although culture can be remarkably persistent, it is inherently evolving; it is shaped and reshaped by the social, political, economic and ecological environment and in turn (re)shapes this environment. To take a specific example, traditional knowledge is not a static or fixed body of information, but should rather be understood as a dynamic learning process that responds to changing circumstances and needs of the group (Becker and Ghimire, 2003; Berkes, 2012).

The third point is aptly described by Weisner (2000: 142): "Cultures may have a clear central tendency and normative pattern, but they are hardly monolithic and uniform." In practice culture is a heterogeneous mix of different cultural models that may concur or conflict with each other. Hence, one can find substantial cultural differences within relatively small groups, and intra-group differences are generally larger than inter-group differences (Shweder, 2000). This feature of culture highlights the importance of detailed micro-level research in understanding the relation between culture and food security.

Finally, a major challenge in conceptualizing culture is identifying its boundaries. For this review, two boundary areas are of importance: between culture and institutions, and between culture and religion. Religion has proven even more difficult to define than culture, and their relation remains a topic of debate. Some scholars see religion as part of culture (e.g. Geertz, 1993; Richerson and Christiansen, 2013), while others argue that there are clear conceptual differences (e.g. Bonney, 2004). Since (a) it is difficult to distinguish between the two in much of the research relevant for this review, and (b) the traits typically associated with religion, such as an explanation of the origin and order of existence and moral codes (Bowie, 2003; Dow, 2007; Iannaccone, 1998), fit well with our understanding of culture, we follow the first approach and treat religion as part of 
culture. Regarding culture and institutions, we follow Alesina and Giuliano (2015) and consider only informal institutions (e.g. social norms) as part of culture.

\subsection{Food security}

Like culture, food security is a multi-dimensional and flexible concept that has been defined in various ways. We use one of the most widely accepted definitions, adopted by FAO in 1996 and refined in 2001; "Food security is a situation that exists when all people, at all times, have physical, social and economic access to sufficient, safe and nutritious food that meets their dietary needs and food preferences for an active and bealthy life" (FAO, 2002). The four accompanying 'pillars' of food security were defined as availability, access, utilization and stability (FAO, 2009).

Food availability focuses on the supply side and refers to the extent to which sources of nutrition are physically available through (local) food production and sales. Food access in turn points to the household's or individual's ability to obtain the food that is available. We pay particular attention to food choice within the discussion of food access because the ability to obtain food does not necessarily translate into actual acquisition (Pinstrup-Andersen, 2009). For the purpose of this review, food utilization concerns the preparation, processing and cooking of foods. Finally, stability is the temporal dimension of food security and includes both the likelihood of experiencing shocks and the ability to recover from them.

It is important to acknowledge that conceptualized in this way, individual food security is a necessary but not sufficient condition for adequate nutrition. As outlined in the UNICEF malnutrition framework (Black et al., 2008), nutrition status is the result of the interplay between food and nutrient intake and health. However, as the effects of culture on health have been discussed elsewhere (e.g. Helman, 2007; Koenig et al., 2012; Spector, 2002), we limit the scope of our review to the impact of culture on the determinants of dietary intake only.

In our review, we focus on direct drivers, leaving aside indirect effects of culture through underlying deeper determinants such as political institutions or economic growth - whose relation with culture has been reviewed elsewhere (e.g. Alesina and Giuliano, 2015; Gershman, 2016; Iyer, 2016; Spolaore and Wacziarg, 2013). However, because income is such an important as a determinant of food access, Section 3.2 briefly discusses available evidence on the impact of culture on income growth.

Finally, it is important to note that aside from its effects on the different pillars of food security (see Section 3), culture may also influence food security measurement (Renzaho and Mellor, 2010). The fact that food distribution practices are strongly culturally determined and contextdependent could for example, affect the accuracy of food consumption or expenditure measures collected at household level that are commonly translated to the individual level through 
assumptions on intra-household food distribution (e.g. equitable distribution) (Carletto et al., 2013). In addition, food habits may affect the extent of recall bias and other sources of measurement error in such survey measures. For instance, the reporting of items that are regularly consumed in similar quantities, may suffer from less recall or telescoping bias in questions about 'consumption in a usual month' compared to irregularly consumed foods. Headey and Ecker (2013) also point out that differences in dietary diversity measures can reflect culturally determined differences in food habits rather than differences in food security drivers or status. Similarly, measures focusing on capturing self-reported perceptions of or behavioural responses to food insecurity can be affected by cultural factors. Depending on the context, the practice of sharing food with neighbours may for example be the result of compliance with social norms rather than a coping strategy related to food insecurity (Renzaho and Mellor, 2010). Nevertheless, recent research has identified classes of responses common across several cultural groups resulting in the development of experiential food insecurity indices such as the Hunger Scale or Household Hunger index. Initial validation exercises suggest that such scales are indeed better suited for cross-cultural food security measurement (Coates et al., 2006; Deitchler et al., 2010).

\section{Culture Affects Food Security in Various Ways}

We organize our discussion of the impact of culture on food security along the lines of the four 'pillars' of food security discussed in Section 2.2. In practice there may not be a strict separation between these pillars, as there are interactions and overlaps between the different channels of impact.

\subsection{Availability}

First, perceptions of what food is can affect the availability of food. Culturally transmitted classifications of available sources of nutrition as food and non-food determine what potential foods are included in the regular diet (Fieldhouse, 1995; Helman, 2007) and thereby influence the composition of local food production, sales, and trade. It is worth noting that such classifications are crucial for the effectiveness of food-based interventions. Englberger (2012) for example reports that a government program in Micronesia aimed at reducing vitamin A shortages failed because it promoted the consumption of green leafy vegetables, which were seen as fodder rather than food for human consumption.

Secondly, culture shapes how food is produced. A growing body of research has analysed the impact of traditional food production ${ }^{4}$ systems and the knowledge embedded therein on food

\footnotetext{
4 Traditional food production refers to the production of foods in a traditional manner (not to the production of traditional foods). We see it as a system that relies on the natural resources available to the group; that has existed for a long period of time; and where production and the embedded knowledge is socially transmitted within the cultural group.
} 
availability (e.g. Altieri, 2004; Clawson, 1985). A noteworthy finding is that certain traditional crop combinations offer agricultural complementarities in the form of resource sharing or protection against environmental stresses (Kumar and Nair, 2004; Milburn, 2004) and a number of traditional crop selection and pest management systems are well adapted to local environments and risks (Abate et al., 2000; Altieri, 2004; Clawson, 1985; Jaenicke and Höschle-Zeledon, 2006). The advantages of the Native American 'three sister' production system for instance are discussed in Box 1

\section{Box 1}

Several traditional production practices have also been documented to result in high agrobiological diversity (Altieri, 2004; Clawson, 1985), which can facilitate dietary diversity (Bélanger and Johns, 2008; Penafiel et al., 2011). It is important to note however, that when food safety checks are absent or insufficient, traditional food production systems may also carry a higher risk of exposure to toxins, either organic (Benkerroum, 2013; Murphy et al., 2006; Wild and Gong, 2010) or inorganic (Isildak et al., 2004; Larsen, 2006; Muhammad et al., 2011; Nabulo et al., 2010).

Since agricultural technology adoption takes place in a social context, culture will also influence producers' acceptance of new food technologies and their willingness to incorporate innovations in food production (Vanclay, 2004). The success of farmer field schools for Filipino rice farmers has for example been attributed to the presence of cultural norms that encourage experiential and collective learning (Palis, 2006).

The efficiency of food production systems in ensuring the availability of sufficient and nutritious foods further depends on post-harvest losses and waste of food. How food is processed and stored is strongly determined by culturally transmitted food processing and storage techniques (e.g. Cardoso et al., 2005; Chipungu et al., 2012; Kittler et al., 2011). ${ }^{5}$ More generally, cultural models of eating may drive food waste behaviour. Public discourse often refers to the emergence of a 'throwaway society' in higher-income countries where food waste is commonplace (Evans et al., 2012; Godfray et al., 2010). Yet, the cultural drivers of food waste are strikingly understudied, and available research strongly focuses on industrialized countries (Blichfeldt et al., 2015; Evans, 2011; Evans et al., 2012).

\subsection{Access and choice}

Food may be physically available, but its intake and the resulting nutrient uptake will depend on a household's and individual's ability to obtain that food. Two major dimensions of access to food are economic access and social access.

\footnotetext{
5 The properties of traditional food processing and storage techniques are analogous to the properties of traditional food production and are discussed in more detail in Section 3.3 on the utilization of food.
} 
Economic access to food is largely determined by income. The relation between culture and economic growth has been reviewed elsewhere (Gershman, 2016; Iyer, 2016; Spolaore and Wacziarg, 2013). These studies generally conclude that there is " a key role for persistent traits transmitted across generations within populations in explaining development outcomes over the very long run" (Spolaore and Wacziarg, 2013: 17). However, it remains difficult to disentangle the effects of culture traits from the effects of other characteristics of human populations, locations, and societies on long-run economic development (Spolaore and Wacziarg, 2013). To our knowledge, the micro-level effects of culture on income have not been systematically reviewed. Available evidence suggests that the relation is highly heterogeneous across a wide diversity of settings, culture traits and channels of impact (e.g. Ager et al., 2014; LeMay-Boucher et al., 2013; Stifel et al., 2011. Bettendorf and Dijkgraaf (2010) for instance find that church membership and other measures of religiosity have different effects on income for high- and low-income households within countries. Hence, the current evidence base does not seem to allow us to draw any general conclusions about the impact of culture on household and individual food access through its effects on income.

By influencing social inclusion, culture shapes social access to food as well. The social transmission of beliefs about groups and individuals (e.g. in the form of stereotypes) can lead to stigmatization and discrimination, and in severe cases result in marginalization through the structural exclusion from social and economic life (Mahajan et al., 2008; Parker and Aggleton, 2003). Some work has for example documented the exclusion of groups and individuals from food assistance programs (e.g. von Braun and Thorat, 2014). Food access can also be undermined through exclusion from regular food acquisition strategies such as food shopping or food production, but this effect has not been systematically researched. In contrast to a large and growing literature on the implications for health (Gabrysch and Campbell, 2009; Mahajan et al., 2008; Smedley et al., 2002; Williams and Mohammed, 2009), less attention has gone to the implications of social exclusion for food security. The situation of indigenous peoples merits particular attention in this respect (King et al., 2009; Stephens et al., 2006). ${ }^{6}$ Although data is limited, indigenous peoples appear to be worse off in terms of food security in any country (Kuhnlein et al., 2006a). The rate of stunting in indigenous communities in Guatemala, El Salvador and Ecuador was for example found to be almost twice as high as the rate among non-indigenous children (UN, 2009). The marginalized status of indigenous peoples is often named as one of the causes of this nutrition gap, but at present a lack of systematic data restricts the possibilities for empirically testing this hypothesis.

\footnotetext{
${ }^{6}$ The definition of indigeneity is complex and contested. We refer to the topical literature (e.g. Stephens et al., 2006) for a detailed discussion.
} 
Culture also determines individual access to food through intra-household food distribution. Important channels of impact are culturally determined beliefs and norms about the value of different types of foods, the order in which different household members are served, and what constitutes a fair share of the meal (Gittelsohn et al., 1997; Harris-Fry et al., 2017). For instance, what is considered a fair share depends on the perceived 'needs' and 'contributions' of household members, which in turn are affected by beliefs about the importance or toughness of different types of work and responsibilities (Engle and Nieves, 1993; Haddad et al., 1996; HarrisFry et al., 2017). There is consensus on the fact that males are often favoured in quantity or quality of food, which can negatively affect food access for girls and women in poor households (e.g. Gittelsohn et al., 1997; Haddad et al., 1996).

Access to food may be further affected by practices regarding how much and what kind of food to offer during feasts or to guests, in particular at large social events such as weddings or funerals (Fieldhouse, 1995). Especially when such practices oblige households to decrease food stocks or slaughter livestock, longer-run household food security could be undermined. A telling example comes from Peru, where food aid targeted to children was served at dinners honouring guests (ACF, 2010). However, in other cases festivities stimulate the consumption of nutrient-rich foods (e.g. Sho, 2001), thus contributing positively to food security. Research on the effects of feasts and festivals on food access remains scarce. Some anthropological work suggests that festivals may actually be a form of institutionalized food redistribution to the poor (or to the rich) (Dietler and Hayden, 2010; Fieldhouse, 1995; Greenberg, 1981).

Culture shapes meal and eating patterns and specifies what constitutes a 'proper' meal and how, when and where one should eat. This can have an important effect on what food is accessible and what food we choose to eat (Atkins and Bowler, 2001; Fieldhouse, 1995; Kittler et al., 2011). Studies of resettled refugees show that the confrontation with unfamiliar cultural models of eating can present significant barriers to food security, in the form of difficulties in navigating the new food environment and preparing unfamiliar foods (e.g. Hadley et al., 2007; Morris et al., 2009; Sheikh-Mohammed et al., 2006).

Socially transmitted food prescriptions (what should be eaten) and proscriptions (what should not be eaten) including food taboos, can affect social access to food and food choice. Such food pre- and proscriptions (collectively referred to as dietary rules) are derived from food classifications according to different criteria, including associated social status, sacredness, or perceived healthiness (Helman, 2007). ${ }^{7}$ There is large heterogeneity in the type, and importance of

\footnotetext{
${ }^{7}$ The distinction between food taboos and non-food classifications is not straightforward. Many studies conflate food taboos and food proscriptions; we prefer to make the distinction as there can be important differences in terms of the strength of underlying norms and enforcement.
} 
dietary rules across and within cultural groups. Even food taboos are not always absolute and can be specific to certain individuals and circumstances (Meyer-Rochow, 2009). Pregnancy, the postpartum period, and infancy are for instance commonly characterized by dietary rules for women and infants (Kim-Godwin, 2003; Piperata, 2008). Yet, though pregnant and lactating women in various parts of the world are forced to abstain from especially nutritious and beneficial food (Barennes et al., 2009; Hartini et al., 2005; Santos-Torres and Vásquez-Garibay, 2003), some studies find that nutrition or energy intake is promoted (e.g. Kaewsarn et al., 2003; Wiley, 2002) or the effects are mixed (e.g. Piperata, 2008; Sein, 2013; Steinberg, 1996).

Overall, the impact of dietary rules also appears to be highly context-specific. A case in point is the impact of religious dietary rules: certain diets and fasting rituals were found to restrict the consumption of foods that are unhealthy in obesogenic environments, while other food-related religious practices had little effect or may be harmful in case of illness, pregnancy, or when access to substitutes is limited (Trepanowski and Bloomer, 2010; Sabaté, 2004).

In general, the impact will depend on the extent to which these rules effectively influence food intake. This in turn depends on how strictly compliance with the behavioural implications of culture traits is enforced. When dietary rules are flexibly enforced, they affect food choice, as compliance will depend on one's assessment of the costs and benefits of observance (Denney et al., 2014; Lee et al., 2009; Raven et al., 2007). These practices can however generate strictly enforced social norms that hamper access to foods that would otherwise be available and affordable (e.g. Meyer-Rochow, 2009; Nwajiuba and Okechukwu, 2006). Besides strong social pressure, strict enforcement can result in a strong internalization of the culture trait as well. Fessler and Navarrete (2003) for instance describe how people's initial explanation as to why an animal is not eaten (e.g. pig among many Muslims) is a feeling of disgust, rather than an explicit taboo or symbolic value. Box 2 illustrates the role of social norms in enforcing food taboos among women in rural Ghana.

\section{Box 2}

Compliance and enforcement can be flexible to varying degrees. Ramadan fasting offers an example of formalized individual flexibility: pregnant, menstruating or breastfeeding women are required to defer Ramadan fasting to a later time to protect their health and that of the foetus or infant (Laway and Ashraf, 2015). However, local beliefs and norms may still override these formal rules and effectively enforce the participation of all adults. In such cases, pregnant women or the ill may become vulnerable to negative food security effects of Ramadan fasting (Almond and Mazumder, 2011; Leiper et al., 2003; Roky et al., 2004; Sabaté, 2004; van Ewijk, 2011). In other cases, flexibility takes the form of tolerance for non-compliance as long as behaviour remains in accordance with underlying cultural models. An example is the compensation of food taboo 
violations by performing neutralizing rituals or eating foods that counteract the negative effects of the violation (Bentley et al., 1999; Meyer-Rochow, 2009). When external enforcement in strong but internalization weak, people may resort to various strategies to circumvent external enforcement, such as secret non-compliance (e.g. Bentley et al., 1999).

There has also been a rising interest in the role of traditional dietary knowledge in shaping food choice and combatting malnutrition. A substantial body of research has studied traditional diets and the embedded dietary knowledge (e.g. Kittler et al., 2011; Kuhnlein et al., 2009; Trichopoulou et al., 2007). It is now widely recognized that a large number of traditional foods ${ }^{8}$ have high nutritional value and are important contributors to nutrition for communities worldwide (Benkerroum, 2013; Burlingame, 2000; Grivetti and Ogle, 2000; Roche et al., 2008; Trichopoulou et al., 2007). An interesting example are the nutritional benefits of 'little millets', as illustrated in Box 3. Moreover, failure to safeguard access to their traditional foods and to preserve the biocultural resources that are the foundations of their diet has been identified as a major driver of poor food security outcomes of indigenous peoples (Kuhnlein et al., 2006a; King et al., 2009; UN, 2015).

\section{Box 3}

Although more research is needed to corroborate these findings in different settings, evidence also suggests that traditional food consumption may be associated with higher dietary diversity (e.g. Boedecker et al., 2014; Penafiel et al., 2011). In addition, cultural groups around the world continue to rely on the age-old strategy of consuming wild foods to cope with short- and long-term food shortages (Bharucha and Pretty, 2010; Burlingame, 2000; Grivetti and Ogle, 2000; Huss-Ashmore and Johnston, 1994). Despite a growing consensus on the potential value of traditional dietary knowledge and the associated consumption of traditional foods, benefits or disadvantages of a wide set of traditional foods remain largely unexplored (Johns and Sthapit, 2004).

Culture further influences food choice by determining consumers' acceptance of new food technologies and innovations. The cultural drivers of food acceptance, and the impact on food choice, have been investigated for industrialized countries, primarily in the context of genetically modified (GM) foods. Finucane and Holup (2005) for instance find that conservative attitudes toward novelty in Germany, a rejection of the US fast food culture associated with GM food in France, and religious values regarding the immorality of disturbing the natural order across Europe,

\footnotetext{
${ }^{8}$ In analogy with the definition of traditional food production, we consider traditional food as food provided by the natural resources available to the group that has been consumed for a long period of time and reflects cultural inheritance, i.e. the production and consumption of the food is socially transmitted within the cultural group (e.g. Guerrero et al., 2009; Roche et al., 2008; Trichopoulou et al., 2007).
} 
reduce acceptance rates of GM foods (see also Curtis et al., 2004; Ronteltap et al., 2007). Research for non-industrialized countries and other food technologies is scarce. Some recent work has explored the cultural drivers of consumer acceptance of bio-fortified maze in low-income countries (De Groote and Kimenju, 2008; Meenakshi et al., 2012; Stevens and Winter-Nelson, 2008), but the evidence base is too limited and too heterogeneous to draw any general conclusions.

Finally, culture also shapes preferences about ideal body sizes (Batnitzky, 2011; Helman, 2007; Olvera et al., 2005), which may affect eating behaviour. Although globally preferences seem to be shifting to thin bodies, large bodies remain the ideal in various cultural groups (e.g. Batnitzky, 2011; Helman, 2007; Micklesfield et al., 2013). Quantitative evidence on the impact of these preferences on food choice and actual body sizes however remains limited, mixed, and likely is confounded by two-way causality since actual body size may affect body size ideals (e.g. Flynn and Fitzgibbon, 1998; Olvera et al., 2005; Swami et al., 2007).

\subsection{Utilization}

How we prepare food is strongly determined by culture (e.g. Fieldhouse, 1995; Kittler et al., 2011; Lawrence and Barker 2009). As Lawrence and Barker (2009:191) put it: "memories from childhood provide images that stay throughout adulthood; thus, homemade or mother's cooking are used as reference points for how food should be prepared and taste". Food preparation involves the combination of different individual foods into meals, and the way these foods are processed. Both have important implications for nutrient intake and absorption as well as the digestibility, palatability, and safety of foods (Milburn, 2004; Ruiz-Rodriguez et al., 2008; Tapsell et al., 2006).

There has been growing interest in the properties of food combinations in traditional food preparation, with various studies finding that certain combinations offer nutritional benefits. Milburn (2004) discusses the example of the dramatically higher protein quality of grains-legumes combinations (e.g. maize and beans in the Americas) compared to the sum of the separate foods due to protein complementarity.

Traditional food processing also continues to play an important role in present-day food preparation (e.g. Benkerroum, 2013; Liu et al., 2011). Certain techniques such as fermentation, soaking, or malting have been identified as cost-effective and energy-efficient ways of improving the nutritional value, safety, palatability, or digestibility of food in diverse settings (e.g. Fandohan et al., 2005; Hotz and Gibson, 2007; Hwang and Lee, 2006; Klayraung et al., 2008; Liu et al., 2011; Makokha et al., 2002). However, as one method can affect food components in different ways, trade-offs take place (Abuajah et al., 2014). Some techniques (e.g. prolonged heating, sun drying) may for instance improve food safety at the expense of nutritional value (Hotz and Gibson, 2007; Lyimo et al., 1991). In addition, there are substantial differences in the performance of different 
traditional processing methods of the same food across groups. Box 4 illustrates this point for the case of traditional cassava processing techniques. Given the important effects of food processing, storage, and preparation on food security, researchers have called for heightened efforts to explore the benefits and risks of a wider set of traditional techniques (Allen and Gillespie 2001; Cardoso et al., 2005; Hotz and Gibson, 2007).

\section{Box 4}

\subsection{Stability}

Culturally transmitted dietary rules have been found to affect the efficiency and sustainability of resource use. The importance of taboos - and more generally cultural or religious beliefs - as frameworks for governing natural resource extraction is gaining widespread recognition. Taboos restricting the consumption or production of certain foods in time or space can for example support species conservation and sustainable resource exploitation and thus contribute to the stability of the food supply (Cinner, 2007; Colding and Folke, 2001; Jones et al., 2008; MeyerRochow, 2009). In other cases the conservation value of taboos, however, appears to be limited. For instance because the group upholding the taboo is too small to have any significant impact (Golden and Comaroff, 2015; Fessler and Navarrete, 2003). Moreover, negative effects can occur when culturally transmitted food prescriptions result in (local) overexploitation of the targeted species - in particular when wild species become commercially traded (Chamberlain et al., 2004). Box 5 discusses an example of effective resource management through taboos among Malagasy communities.

\section{Box 5}

In addition, traditional food crops often demonstrate higher resilience and lower care needs compared to non-indigenous cultivated foods. A number of studies also finds that traditional crop selection and pest management systems may contribute to the stability of food production, as some have been found to be particularly well adapted to local environments and shocks, for instance through the use of crop varieties that are resistant to different types of environmental stresses, have different growing periods and durations, or have different nutritional requirements (Abate et al., 2000; Altieri, 2004; Clawson, 1985). The property of higher resilience and resistance to different types of environmental stresses is particularly attractive in a context of increasing climatological risk and uncertainty.

Finally, as mentioned above, culture influences processing and storage of food, which can promote longer shelf life. This can in turn mitigate constraints such as seasonality and poorly functioning markets (Keding et al., 2013) and contribute to the stability of food consumption.

\section{Gender, Family and Decision-Making Power}


At the individual and household level, gender, family, and decision-making power are key crosscutting determinants that interact with most, if not all, channels through which culture affects food security.

\subsection{Gender}

Each society is characterized by a "set of guidelines, both implicit and explicit, that are acquired from infancy onwards, and tell the individual how to perceive, think, feel and act as either a male or female member of that society" (Helman, 2007: 158). These cultural gender models are of paramount importance when discussing the impact of culture on food security. First, gender can determine directly what preferences, beliefs, norms, and practices one is expected to display or observe. For instance, women often face a larger number of food pre- and proscriptions due to their reproductive role (Bentley et al., 1999; Odebiyi, 1989; Meyer-Rochow, 2009). In addition, other gender-specific social norms that are not directly related to food can influence food security as well. Ravindran et al. (1986) for example describes how in Haryana, India, cultural restrictions on adolescent girls' freedom to leave their homes limit their physical access to significant sources of dietary diversity. Such gender effects call for caution in extrapolating evidence on the impact of culture from men to women and vice versa.

Second, gender will often interact with effects of culture. Gender roles within the household, notably the division of household labour, are particularly important in the context of culture and food security as they interact with many channels of impact such as dietary practices and intra-household food distribution (Moss, 2002; Piperata, 2008). For instance, the impact of food taboos on individual food access can depend on who is in charge of food purchases in the household. Box 6 offers further illustration by discussing the interaction between gender roles and traditional dietary and behavioural postpartum practices in the Eastern Amazon.

\section{Box 6}

\subsection{Family}

Family structures, including the different relations and responsibilities of family members, can interact with the food security effects of culture in three important ways. First, family life plays a crucial role in the development of eating habits, among others through socialization into cultural models, parental modelling, and exposure at home (Birch and Fisher, 1998; Patrick and Nicklas, 2005; Taylor et al., 2005; WHO, 2012). There is extensive evidence for an indirect long-term impact of infant and child feeding practices on food security through the development of food preferences in later life (Birch and Fisher, 1998; Taylor et al., 2005; Wardle and Cooke, 2008). For instance, serving sugar-rich foods in positive contexts (e.g. celebrations) can strengthen children's innate preference for sweet foods, which may promote overnutrition in later life (Birch and Fisher, 1998; Birch, 1999). 
Second, mothers often share home care and child feeding responsibilities with other family members - in particular grandmothers - who may have a large or even primary influence in these areas. Fouts and Brookshire (2009) for instance find that among the Aka foragers in Congo, mothers gave food to children less frequently than other family members combined (e.g. fathers, grandmothers, aunts).

Third, the preferences and beliefs of recipient family members can influence the choices of caregivers (e.g. in home care, cooking, etc.) to varying degrees (Just et al., 2007; Lawrence and Barker 2009).

\subsection{Decision-making power}

Gender models and family relations are of course closely linked to decision-making power. The main locus of power in decision-making processes varies across cultural groups, from highly individualistic models to highly collectivist models where the locus of power lies mainly with the community (Hammoud et al., 2005; McLaughlin and Braun, 1998). Individual decision-making power within groups depend on a variety of factors, but are commonly associated with gender, age, and social status. In many cultural groups, elders are important decision makers in the family and community, and in that function play a key role in preserving, transmitting, and changing culture traits (e.g. Aubel, 2012; Bezner Kerr et al., 2008; Fouts and Brookshire, 2009; Geçkil et al., 2009; Kaewsarn et al., 2003; Raven et al., 2007).

Decision-making power is a major mediating factor in the relation between culture and food security. Who decides when and what food to buy or produce, or how to distribute it within the household, to give a few examples, can have a crucial influence on the impact of culture traits (e.g. Denney et al., 2014; Lori and Boyle, 2011; McLaughlin and Braun, 1998; Scott et al., 2014). This also implies that who provides and who receives information matters a great deal for the impact of information interventions on behaviour.

\section{Dynamic Aspects of the Culture-Food Relation and Drivers of Change}

As mentioned before, culture is dynamic and evolving, often changing in response to a changing environment. Food and non-food classifications, for instance, can change in times of food shortages (Fessler and Navarrete, 2003; Helman, 2007). However, culture can also be a powerful and emotionally held preserver of stability and predictability, strongly resisting change (Fieldhouse, 1995; Weisner, 2000). Even in situations of extreme starvation, for instance, groups may hold on to food taboos (Helman, 2007). Malagasy dietary rules illustrate this duality well: whereas one type of proscriptions is perceived as negotiable and people can ask their ancestors to free them in times of need, breaking other extremely strict taboos is always expected to lead to illness or misfortune (Jones et al., 2008). 
The questions of when, how, and why culture changes or persists are at the centre of a growing body of theoretical and empirical research across disciplines (see e.g. Alesina et al., 2013; Boyd and Richerson, 2004; Gershman, 2015; Henrich and McElreath, 2003; Lee et al., 2009; Mesoudi, 2011). Existing theories continue to be debated, and a full discussion of the topic exceeds the scope of this paper. We instead highlight the question of how modernization relates to cultural change, which has received particular attention in recent years.

Classic modernization theory states that traditional values, beliefs, and customs - especially religion and supernatural belief systems - will inevitably disappear with rising urbanization, education, and the spread of scientific and technological advancements (Iannaccone, 1998; Inglehart, 2016). However, many scholars have criticized this theory. Inglehart (2016) for instance proposes an evolutionary modernization theory, in which modernization is said to increase economic and physical security levels, which creates important cultural changes in similar directions. Yet, because culture is highly persistent, these cultural changes are path-dependent and reflect historically determined cultural differences. A case in point is the continued and possibly growing vitality of witchcraft beliefs in sub-Saharan Africa (e.g. Gershman, 2016b; Kohnert, 2007; Leistner, 2014), or the continued importance of religion outside of Europe and its offshoots (Iannaccone, 1998). The take-away message is that modernization processes and income growth can cause important cultural change following, but this does not necessarily erode cultural differences or the historically shaped core characteristics of a culture.

\subsection{Change and persistence in the cultural drivers of FNS}

In the context of food security, we indeed see both cultural change and persistence. Research has documented cases where modernization and economic development are associated with a loss of traditional knowledge (Gómez-Baggethun et al., 2010; Gómez-Baggethun et al., 2013; ReyesGarcía et al., 2013) and an erosion in adherence to certain food-related culture traits (e.g. Lilette, 2006; Piperata, 2008; Englberger et al., 2003). Indigenous peoples have often experienced particularly drastic dietary changes following the modernization of food systems - although the degree to which traditional food systems disappeared varies considerably (Kuhnlein et al., 2009).

Then again, an illustration of the persistence of food habits is the fact that in many regions the dominant staple crop continues to be the crop that was endemic to that ecological zone, i.e. the crop that was eaten by pre-industrial societies (Atkins and Bowler, 2001). More generally, research documents various cases where in spite of broad societal changes including migration ${ }^{9}$

\footnotetext{
${ }^{9}$ Migration flows (i.e. the arrival of outsiders who do not adhere to the same rules) can lead to cultural erosion (e.g. Maarleveld and Dangbégnon, 1999; Kaufmann et al., 2006).
} 
and the spread of Western religion, food-related cultural models have remained relatively intact (e.g. Golden and Comaroff, 2015b; Jones et al., 2008).

The question of when and how cultural models of eating and food habits change remains highly complex and poorly understood. New information appears to be a major driver of cultural change, as it alters the socially transmitted information set that is culture. In particular, change seems to occur when new information is linked to existing cultural models, facilitating acceptance and integration of the new information or the reinterpretation of pre-existing knowledge (Aubel et al., 2004; Bezner Kerr et al., 2008; Kuhnlein et al., 2013; Semega-Janneh et al., 2001).

In this light, research on the impact of migration - which entails exposure to new information and different culture traits - can offer insights into the question of how and when cultural models of eating and food habits change. Chowdhury et al. (2000) for example find that Bangladeshi migrants in the UK largely maintained their traditional dietary habits. Gilbert and Khokhar (2008) find that some immigrant populations in Europe spend significantly more on preserving their food habits than others, regardless of socio-economic status. The authors suggest that the extent of dietary acculturation may depend on the value placed on one's original food habits and those in the host country, as well as the availability and accessibility of foods from the original diet. Generation and age also appear to play an important role. Younger generations of Pakistani migrants in the UK were for example more likely to change their eating habits as British foods were seen as convenient, associated with the host country, and reflective of adventure and independence (Jamal, 1998).

\subsection{Globalization, cultural change, and shifts in diets and food habits}

An important recent development in this context is the large-scale global shift in human diets and food habits in similar directions (high consumption of saturated fats and sugars, highly processed foods, and out-of-home meals), a phenomenon often referred to as the 'nutrition transition' (Chopra et al., 2002; Kearney, 2010; Keats and Wiggins, 2014; Monteiro et al., 2013; Popkin et al., 2012). However, it remains unclear to what extent this global shift in diets reflects cultural change, and to what extent it is a consequence of the globalization of food systems. These processes are of course not mutually exclusive, as food system changes can generate cultural change and vice versa. Recent studies on alcohol consumption patterns for example argue that in combination with income growth, globalization has increased access to foreign investment and new products, as well as the spread of knowledge and information on these products, ultimately giving rise to a global convergence of alcohol consumption patterns (Anderson et al., 2018 Colen and Swinnen, 2016; Swinnen and Briski, 2017). Other studies also suggest that the globalization of food systems along with the globalization of information and communication technologies (ICT) and mass media 
spreads cultural lifestyle and eating models (e.g. fast food) (Huynen et al., 2005; Keats and Wiggins, 2014). Yet, there is little rigorous research regarding the relative importance of cultural drivers and socio-economic or supply side factors in the nutrition transition. ${ }^{10}$

\subsection{Mass media, marketing, and changing cultural models}

Media and marketing are a major source of information for the public and thereby both reflect and shape culture traits (Wakefield et al., 2003). Mass media is increasingly visible and accessible through ICT developments such as mobile internet connection, and marketing has expanded far beyond simple advertising into marketing environments that include sales promotions, websites, viral marketing, music and sports sponsorship, product placement in films and television, and inschool marketing (Hawkes, 2006; Kretchmer, 2004).

It is important to note that though advertising is now a global phenomenon (Hawkes, 2006), research on the nature and impact of media and marketing in developing countries is scarce. Available evidence from developed countries shows that media and marketing have a strong effect on food choice (Cairns et al., 2013; Cohen, 2008; Harris et al., 2009; Taylor et al., 2005). Three broad mechanisms are at play. First, marketing affects automated, uncontrollable responses through environmental cues, such as the placement of products in supermarkets (Cohen 2008). Second, the omnipresence of media and marketing in everyday life and popular culture shapes habits and preferences by creating powerful cultural models of food, health, and lifestyle that consumers are driven to emulate (Atkins and Bowler, 2001; Nestle et al., 1998; Wakefield et al., 2003). Exposure to mass media has for example been associated with internalization of a thin body ideal and changes in women's eating behaviours and beliefs (Grabe et al., 2008). Third, media affects perceptions of the risks and benefits of foods (Cairns et al., 2013; McCluskey and Swinnen, 2004; Taylor et al., 2005). ${ }^{11}$

As for the direction of impact, both positive and negative effects occur. On the one hand, the powerful influence of media and marketing can be detrimental to food security. Marketing generally induces overconsumption (Anderson et al., 2009; Cohen 2008; Lovato et al., 2011). Food marketing is also often heavily oriented toward low-nutrition, obesogenic foods and beverages and has been shown to increase the consumption of these foods (Cairns et al., 2013; Dixon et al., 2007; Harris et al., 2009; Monteiro, 2009). Box 7 offers details for the case of television advertising targeted to children.

\section{Box 7}

\footnotetext{
${ }^{10}$ Watson (2006) offers an in-depth study of the rise of McDonald's in East Asia, and argues that its success in Beijing is driven by associations with freedom, democracy, and 'world citizenship', rather than the taste or convenience of the food.

${ }^{11}$ This media effect seems to explain a significant part of between-country differences in regulations concerning GM foods (Vigani and Olper, 2015).
} 
In addition, marketing is often aggressively targeted to children and adolescents with the aim of shaping long-term food habits, and may thereby affect long-run food security already from a young age (Cairns et al., 2013; Harris et al., 2009; Wakefield et al., 2003). Dekoninck and Swinnen (2015) for example argue that particularly for young adults, advertising played an important role in the rise of beer consumption in Russia. Finally, the information transmitted by media and marketing does not necessarily conform to the best scientific knowledge and may include misleading nutrition claims, thereby contributing to misinformation about food (Abrahams et al., 2016; Keats and Wiggins, 2014; Nestle et al., 1998; Taylor et al., 2005).

On the other hand, the power of media and marketing can also be used to promote positive behavioural change (Randolph and Viswanath, 2004; Snyder, 2007; Wakefield et al., 2010). Public mass media information campaigns appear to have small but positive effects on changing eating behaviours (e.g. Matson-Koffman et al., 2005; Pomerleau et al., 2005; Snyder et al., 2004). Experiments with the use of social media and digital technologies for promoting desirable diet and health behaviour show promise, but further research is needed to draw conclusions about behavioural impact and to tackle the specific challenges of these new types of media (e.g. how to control information quality on social media) (Higgs et al., 2014; Korda and Itani, 2013; Moorhead et al., 2013).

\section{Conclusions and implications for policy and research}

This review has shown that what we eat, as well as how and why we obtain, process, store, prepare, share, and eat food, is affected by culture in various ways. Some channels of impact, such as food taboos, have been extensively researched, while for others such as the cultural drivers of food waste the literature is still in its infancy. In many cases available research is heavily oriented toward highcome countries. Overall, empirical evidence on the impact of cultural drivers of food security appears to be mixed and varies across different cultural groups and socio-economic settings for most channels of impact, making it difficult to draw general conclusions. Despite this, we try to formulate some conclusions and recommendations as to how policy can use existing knowledge on the impact of culture to improve food security, and identify areas for future research.

Culture is often mentioned as a fundamental driver of food security by development practitioners and policy-makers. Yet, little progress has been made in terms of integrating and mainstreaming it into food security policies and interventions in practice. Perhaps the most obvious and widely recognized way in which culture should be taken into account is by ensuring the availability of foods that meet culturally determined preferences. ${ }^{12}$ Still, the use of culturally

\footnotetext{
12 The condition of meeting food preferences was for example added to the FAO (1996) definition of food security because of concerns related to the cultural acceptability of foods in different contexts (Pinstrup-Andersen, 2009).
} 
inappropriate foods remains a common cause of failure of supplementary feeding programs (Allen and Gillespie, 2001). Barrett (2006) for example documents how food aid in the form of maize to Kenyan pastoralists, whose traditional diet is largely based on animal source foods, was not consumed but instead processed into home brewed alcohol. Similarly, failure to safeguard the availability of and access to culturally appropriate foods has been identified as a major driver of poor food security outcomes of indigenous peoples (Kuhnlein et al., 2006a; UN, 2009).

The effectiveness of campaigns targeted at behavioural change is particularly dependent on how culture is taken into account as well (Kreuter and Haughton, 2006; Winham, 2009). First, the impact of information on behaviour will strongly depend on who provides and who receives information. The fact that information interventions are usually targeted at mothers and young reproductive women, thus bypassing existing gender, family, and power relations, may explain why many have not led to sustained behavioural change (Allen and Gillespie, 2001; Bezner Kerr et al., 2008; Cornwall, 2003). An improved understanding of cultural models of gender, family and decision-making power is therefore crucial to make sure that the most relevant decision-makers or persons of influence are involved. There is growing evidence that the inclusion of family and community members and other peers has positive effects (e.g. Kuhnlein et al., 2013; PérezEscamilla et al., 2008; Semega-Janneh et al., 2001). ${ }^{13}$ Aubel et al. (2004) provide an illustrative example of an intervention which specifically aimed to test the impact of involvement of grandmothers in providing nutrition and health information to pregnant mothers in Senegal. The results showed sustained positive behavioural changes among grandmothers (e.g. different advice) and mothers (e.g. increased food intake during pregnancy, improved breastfeeding and complementary feeding practices) only when grandmothers were involved, affirming their key role in turning new health information into new practice.

Second, information that is culturally appropriate and builds upon certain culture traits may be more effective in capturing attention, stimulating information processing, and ultimately motivating behavioural change. Allen and Baines (2002) for example report evidence from an experiment that suggests that individuals can be persuaded to alter their diets by stressing certain values symbolised by a food product rather than focusing exclusively on nutritional arguments. Kuhnlein (2004) also argues that interventions may be more successful when they focus on stimulating the use of health-promoting traditional foods and dietary practices. The promotion and reintroduction of traditional foods may therefore also be a useful component of strategies to tackle

\footnotetext{
${ }^{13}$ See McLean et al. (2003) for interventions where the impact remains largely unclear. The impact of involving husbands in reproductive and maternal-child health interventions is more mixed (Kraft et al., 2014; Midhet and Becker, 2010; Mullany et al., 2007; Sternberg and Hubley, 2004), possibly because husbands are not always the most relevant decision-makers in this area in the study populations.
} 
the double burden of malnutrition in high-income settings (Johns and Sthapit, 2004). Such strategies are of particular interest in light of recent trends of reviving local traditional or artisanal food cultures, which is argued to constitute a counter-reaction to the spread of fast food and highly processed foods associated with the nutrition transition (Pieniak et al., 2009; Wilk, 2006).

Besides cultural acceptability, certain traditional foods have also been documented to offer one or several of the following benefits: high levels of micronutrients, (natural) availability, affordability, and higher resilience and lower care needs. As such, when developing food-based strategies, it is worthwhile to explore traditional diets and gather information on the nutrition, antinutritional and toxic content of traditional foods, taking into account the impact of food production, processing, and preparation techniques, and (in)organic contamination, in order to identify and promote the use of traditional foods that can contribute to food security. The possible economic, social and ecological implications of these interventions should be investigated as well, since they can be highly heterogeneous across communities depending on the dietary, cultural, or economic value of the food (Kuhnlein et al., 2013; Termote et al., 2011).

Improving the integration of culture may also enhance the effectiveness of productionoriented policies and interventions. There is growing recognition of the potential value of culture and the embedded knowledge for realizing sustainable, accessible, and qualitative food production systems. In some cases, traditional knowledge can offer a useful repository of alternative technologies that are particularly compatible with local food systems and cultural models, accessible, familiar, easy to use, and low-cost. Certain agro-ecological farming (Altieri, 2004; Pangaribowo et al., 2013) and climate change coping strategies (Stigter et al., 2005) were for example modelled after successful traditional agricultural systems. Similarly, especially when other food technologies such as fridges or pasteurization are inaccessible or inappropriate for local conditions, traditional food processing and storage techniques can serve as inspiration. For instance, in eastern Africa where access to electricity remains limited in some areas, traditional pots of unbaked clay were found to act as an efficient replacement for a refrigerator to store milk, due to the cooling effect of evaporation (Roesel et al., 2015). Based on research and experimentation, such techniques can be further transformed in collaboration with local producers and consumers to improve the productivity and resilience of food production and the safety, efficiency, and effectiveness of food processing, storage, and preparation (Abate et al., 2000; Hotz and Gibson, 2007). A successful example of this strategy is the improvement of a traditional cassava processing method into the so-called wetting method, which rapidly reduces the cyanide content of cassava flour, in addition to improving taste and storage possibilities (Bradbury, 2006; Bradbury and Denton, 2010; Cumbana et al., 2007). Being simple and based on traditional techniques, the method 
has shown promise in terms of acceptance rates and positive food security effects (Banea et al., 2012; 2013). If policy is to take advantage of the potential benefits of traditional food systems, however, more efforts are needed to document and preserve these food systems and the underlying biological and cultural resources. ${ }^{14}$

Participatory approaches based on dialogue and information sharing rather than top-down, directive, and expert-led interventions, may be especially suitable to take culture into account in practice. ${ }^{15}$ Such approaches are more likely to result in multifaceted strategies that consider a broad range of cultural variables. This in turn facilitates the tailoring of interventions to local contexts and the acceptance and integration of new information in existing cultural models (e.g. Kuhnlein et al., 2013; Semega-Janneh et al., 2001). In the area of agricultural development, the possible advantages of these approaches are well established (e.g. Abate et al., 2000; Bezner Kerr et al., 2007). For other drivers of food security considered in this review, they are still less common, though some existing interventions have produced encouraging results (e.g. Aubel et al., 2004; Kuhnlein et al., 2013).

One could draw useful lessons from the health sector on how to take culture better into account in the area of food security. The practice of giving cultural training to health care providers (e.g. Betancourt et al., 2003; Spector, 2002), can serve as inspiration to improve the cultural competence of those involved in the delivery of various food security interventions. Another strategy consists of adjusting logistics to ease cultural barriers in accessing health services. Delivering perinatal care at home or facilitating accompanied travel to medical facilities for example eases constraints presented by gender norms on mobility (Mumtaz and Salway, 2005). The same could hold for delivery of food assistance or nutrition information.

There has also been a rising interest for a better integration of traditional and biomedical health services in research and policy (e.g. Homsy et al., 2004; WHO, 2013; Zhang et al., 2011). The fact that these are founded on different (possibly conflicting) illness and health models does not necessarily pose a problem: patients and providers are found and stimulated to make different models compatible by reinterpreting biomedical information and practices through the lens of local models, or by adapting beliefs and practices so as to make them consistent with newly acquired information (Adams et al., 2005; Obermeyer, 2000; Scott et al., 2014; Wiley, 2002). Research on the feasibility and desirability of an institutionalized integration of traditional and biomedical health services has identified the different advantages, risks, and potential obstacles (King, 2000; Mills et

\footnotetext{
${ }^{14}$ In many cases these bio-cultural resources are disappearing at a fast rate (Burlingame and Dernini, 2012). Kuhnlein et al. (2006b; 2009) provide a detailed description of a protocol for documenting traditional food systems of indigenous peoples, and apply this to various indigenous peoples worldwide.

${ }^{15}$ See Cornwall (2003) for a critique on the current use of participatory approaches to development.
} 
al., 2006). A better integration of beneficial traditional foods and traditional production, processing, and cooking methods into food systems likely faces many similar benefits, risks, and obstacles. In addition, government programs to foster health care integration that are currently being implemented in various countries (e.g. Aissan et al., 2013; Kayombo et al., 2007) may offer important insights for the design and implementation of similar interventions in the area of food security.

Finally, there are several areas for future research. A major gap in our understanding remains how important cultural effects are relative to other drivers, such as socio-economic (prices, income, education) or environmental factors (food availability, remoteness). A small body of qualitative and quantitative work has tried to shed light on the relative importance of cultural drivers in the context of food security. In some cases cultural variables are argued to dominate economic or environmental determinants (Atkin, 2016; Choudhury and Ahmed, 2011; Watson, 2006), while in other cases culture seems to play a secondary role (e.g. Goldman et al., 2002; Hartini et al., 2005).

One possible reason for the paucity of systematic research analysing and comparing cultural, economic, and environmental effects on food security is the qualitative or descriptive nature of a large part of the literature, with limited information on the size of cultural effects. A first step toward an improved understanding of the relative importance of culture thus lies in the quantification of its impact on different aspects of food security. Both on the consumption side and the production side, however, major data gaps remain. For instance, in contrast to a large literature on the role of culture in health gaps for marginalized groups (e.g. Helman, 2007; Smedley et al., 2002), little is known regarding food security gaps. To understand the extent to which cultural factors contribute to poor food security of severely marginalized groups such as indigenous peoples there is an urgent need for systematic and comprehensive data collection on both cultural drivers of food security and needs and outcomes for marginalized groups (Stephens et al., 2006).

A second vital question that remains poorly understood relates to the dynamics of culture. Although notable progress has been made in various disciplines toward understanding the origins and evolution of culture, the question of when, how, and why culture changes or persists remains a highly complex one that is intertwined with environmental, social, economic, and politicoinstitutional change. For instance, while both change and persistence have been clearly observed, it remains unclear when and how cultural models of eating and food habits change. In this context, the rapid growth and spread of new information and communication technologies (ICT) is of particular interest. Recent research suggests that new global marketing campaigns, the rise of social media, and the rapid spread of mobile phones in developing countries can affect food preferences 
and dietary knowledge (e.g. Abrahams et al., 2016; Dixon et al., 2007; Rutsaert et al., 2013). Yet, overall we know little of the effects on cultural drivers of food security. Since ICT technologies can be expected to develop and spread further, more research is needed to improve our understanding of their potential effects and the implications for food security policy. For instance, future research could explore how to curb any negative food security effects and how ICT technologies can be usefully incorporated in food security strategies. 


\section{References}

Abate, T., Huis, A. van, Ampofo, J.K.O., 2000. Pest Management Strategies in Traditional Agriculture: An African Perspective. Annual Review of Entomology 45, 631-659. https://doi.org/10.1146/annurev.ento.45.1.631

Abrahams, Z., Temple, N.J., Mchiza, Z.J., Steyn, N.P., 2016. A Study of Food Advertising in Magazines in South Africa. Journal of Hunger \& Environmental Nutrition 0, 1-13. https://doi.org/10.1080/19320248.2016.1227757

Abuajah, C.I., Ogbonna, A.C., Osuji, C.M., 2014. Functional components and medicinal properties of food: a review. J Food Sci Technol 52, 2522-2529. https://doi.org/10.1007/s13197-014-1396-5

ACF, 2010. Considering Culture in Nutrition and Food Systems: An innovative approach to reducing chronic child malnutrition, ACF Policy Brief 2.

Adams, V., Miller, S., Chertow, J., Craig, S., Samen, A., Varner, M., 2005. Having A Safe Delivery?: Conflicting Views from Tibet. Health Care for Women International 26, 821 851. https://doi.org/10.1080/07399330500230920

Ager, P., Hansen, C.W., Lønstrup, L., 2014. Church Membership and Social Insurance: Evidence from the American South (Discussion Papers No. 14-29). Department of Economics, University of Copenhagen.

Aissan, J., Bokossa, Y., Dresse, A., Zinsou, F., 2013. Les Acquis du Projet de Recherche-Action "Interface entre Prestataires de Soins Officiels et Traditionnels" dans la Zone Sanitaire de Klouékanmè-Toviklin-Lalo.

Alesina, A., Giuliano, P., 2015. Culture and Institutions. Journal of Economic Literature 53, 898944. https://doi.org/10.1257/jel.53.4.898

Alesina, A., Giuliano, P., Nunn, N., 2013. On the Origins of Gender Roles: Women and the Plough. The Quarterly Journal of Economics 128, 469-530. https://doi.org/10.1093/qje/qjt005

Allen, L., Gillespie, S., 2001. What works? A review of the efficacy and effectiveness of nutrition interventions, License: CC BY 3.0 IGO. Asian Development Bank, Manila, Philippines.

Allen, M.W., Baines, S., 2002. Manipulating the symbolic meaning of meat to encourage greater acceptance of fruits and vegetables and less proclivity for red and white meat. Appetite 38, 118-130. https://doi.org/10.1006/appe.2001.0474

Altieri, M., 2004. Linking ecologists and traditional farmers in the search for sustainable agriculture. Frontiers in Ecology and the Environment 2, 35-42. https://doi.org/10.1890/1540-9295(2004)002[0035:LEATFI]2.0.CO;2

Altieri, M.A., 1999. The ecological role of biodiversity in agroecosystems. Agriculture, Ecosystems \& Environment 74, 19-31. https://doi.org/10.1016/S0167-8809(99)00028-6

Anderson, P., Bruijn, A. de, Angus, K., Gordon, R., Hastings, G., 2009. Impact of Alcohol Advertising and Media Exposure on Adolescent Alcohol Use: A Systematic Review of Longitudinal Studies. Alcohol and Alcoholism 44, 229-243. https://doi.org/10.1093/alcalc/agn115

Anderson, K, Meloni, G., Swinnen, J., 2018. Global Alcohol Markets: Evolving Consumption Patterns, Regulations and Industrial Organizations. Annual Review of Resource Economics (forthcoming).

Arzoaquoi, S.K., Essuman, E.E., Gbagbo, F.Y., Tenkorang, E.Y., Soyiri, I., Laar, A.K., 2015. Motivations for food prohibitions during pregnancy and their enforcement mechanisms in a rural Ghanaian district. Journal of Ethnobiology and Ethnomedicine 11, 59. https://doi.org/10.1186/s13002-015-0044-0

Atkin, D., 2016. The Caloric Costs of Culture: Evidence from Indian Migrants. American Economic Review 106, 1144-1181. https://doi.org/10.1257/aer.20140297 
Atkins, P., Bowler, I., 2001. Food in society: economy, culture, geography. Arnold, London; New York.

Aubel, J., 2012. The role and influence of grandmothers on child nutrition: culturally designated advisors and caregivers. Maternal \& Child Nutrition 8, 19-35. https://doi.org/10.1111/j.1740-8709.2011.00333.x

Aubel, J., Touré, I., Diagne, M., 2004. Senegalese grandmothers promote improved maternal and child nutrition practices: the guardians of tradition are not averse to change. Social Science \& Medicine 59, 945-959. https://doi.org/10.1016/j.socscimed.2003.11.044

Banea, J.P., Bradbury, J.H., Mandombi, C., Nahimana, D., Denton, I.C., Kuwa, N., Tshala Katumbay, D., 2013. Control of konzo by detoxification of cassava flour in three villages in the Democratic Republic of Congo. Food and Chemical Toxicology 60, 506-513. https://doi.org/10.1016/j.fct.2013.08.012

Banea, J.P., Nahimana, G., Mandombi, C., Bradbury, J.H., Denton, I.C., Kuwa, N., 2012. Control of konzo in DRC using the wetting method on cassava flour. Food and Chemical Toxicology 50, 1517-1523. https://doi.org/10.1016/j.fct.2012.02.001

Barennes, H., Simmala, C., Odermatt, P., Thaybouavone, T., Vallee, J., Martinez-Ussel, B., Newton, P.N., Strobel, M., 2009. Postpartum traditions and nutrition practices among urban Lao women and their infants in Vientiane, Lao PDR. Eur J Clin Nutr 63, 323-331. https://doi.org/10.1038/sj.ejcn.1602928

Barrett, C.B., 2006. Food aid's intended and unintended consequences, Background Paper for FAO State of Food and Agriculture.

Batnitzky, A.K., 2011. Cultural constructions of “obesity": Understanding body size, social class and gender in Morocco. Health \& Place, Health Geographies of Voluntarism 17, 345 352. https://doi.org/10.1016/j.healthplace.2010.11.012

Becker, Cd., Ghimire, K., 2003. Synergy between traditional ecological knowledge and conservation science supports forest preservation in Ecuador. Ecology and society 8, 1.

Bélanger, J., Johns, T., 2008. Biological Diversity, Dietary Diversity, and Eye Health in Developing Country Populations: Establishing the Evidence-base. EcoHealth 5, 244-256. https://doi.org/10.1007/s10393-008-0180-2

Benkerroum, N., 2013. Traditional Fermented Foods of North African Countries: Technology and Food Safety Challenges With Regard to Microbiological Risks. Comprehensive Reviews in Food Science and Food Safety 12, 54-89. https://doi.org/10.1111/j.15414337.2012.00215.x

Bentley, G.R., Aunger, R., Harrigan, A.M., Jenike, M., Bailey, R.C., Ellison, P.T., 1999. Women's strategies to alleviate nutritional stress in a rural African society. Social Science \& Medicine 48, 149-162. https://doi.org/10.1016/S0277-9536(98)00330-X

Berkes, F., 2012. Sacred Ecology. Routledge.

Betancourt, J.R., Green, A.R., Carrillo, J.E., Ananeh-Firempong, O., 2003. Defining cultural competence: a practical framework for addressing racial/ethnic disparities in health and health care. Public Health Rep 118, 293-302.

Bettendorf, L., Dijkgraaf, E., 2010. Religion and income: Heterogeneity between countries. Journal of Economic Behavior \& Organization 74, 12-29. https://doi.org/10.1016/j.jebo.2010.02.003

Bezner Kerr, R., Dakishoni, L., Shumba, L., Msachi, R., Chirwa, M., 2008. “We Grandmothers Know Plenty": Breastfeeding, complementary feeding and the multifaceted role of grandmothers in Malawi. Social Science \& Medicine 66, 1095-1105. https://doi.org/10.1016/j.socscimed.2007.11.019

Bezner Kerr, R., Snapp, S., CHIRWA (deceased), M., Shumba, L., Msachi, R., 2007. Participatory research on legume diversification with Malawian smallholder farmers for improved human nutrition and soil fertility. Experimental Agriculture 43, 437-453.

https://doi.org/10.1017/S0014479707005339 
Bharucha, Z., Pretty, J., 2010. The roles and values of wild foods in agricultural systems. Philosophical Transactions of the Royal Society B: Biological Sciences 365, 2913-2926. https://doi.org/10.1098/rstb.2010.0123

Birch, L.L., 1999. Development of Food Preferences. Annual Review of Nutrition 19, 41-62. https://doi.org/10.1146/annurev.nutr.19.1.41

Birch, L.L., Fisher, J.O., 1998. Development of Eating Behaviors Among Children and Adolescents. Pediatrics 101, 539-549.

Black, R.E., Allen, L.H., Bhutta, Z.A., Caulfield, L.E., De Onis, M., Ezzati, M., Mathers, C., Rivera, J., 2008. Maternal and child undernutrition: global and regional exposures and health consequences. The lancet 371, 243-260. https://doi.org/10.1016/S01406736(07)61690-0

Blichfeldt, B.S., Mikkelsen, M., Gram, M., 2015. When it stops being food: The edibility, ideology, procrastination, objectification and internalization of household food waste. Food, Culture \& Society 18, 89-105.

Boedecker, J., Termote, C., Assogbadjo, A.E., Damme, P., Lachat, C., 2014. Dietary contribution of Wild Edible Plants to women's diets in the buffer zone around the Lama forest, Benin - an underutilized potential. Food Sec. 6, 833-849. https://doi.org/10.1007/s12571-0140396-7

Bonney, R., 2004. Reflections on the differences between religion and culture. Clinical cornerstone 6, 25-33. https://doi.org/10.1016/S1098-3597(04)90004-X

Bowie, F., 2003. Anthropology of religion, in: Segal, R.A. (Ed.), The Blackwell Companion to the Study of Religion. Blackwell Publishing, pp. 3-24.

Boyd, R., Richerson, P.J., 2004. The Origin and Evolution of Cultures. Oxford University Press, New York.

Bradbury, J.H., 2006. Simple wetting method to reduce cyanogen content of cassava flour. Journal of Food Composition and Analysis, After Processing: The Fate of Food Components 19, 388-393. https://doi.org/10.1016/j.jfca.2005.04.012

Bradbury, J.H., Denton, I.C., 2010. Rapid wetting method to reduce cyanogen content of cassava flour. Food Chemistry 121, 591-594. https://doi.org/10.1016/j.foodchem.2009.12.053

Burlingame, B., 2000. Wild nutrition. Journal of Food Composition and Analysis 13, 99-100.

Burlingame, B., Dernini, S., 2012. Sustainable diets and biodiversity - Directions and solutions for policy, research and action, International Scientific Symposium Biodiversity and sustainable diets united against hunger (2010: Rome, Italy). FAO.

Cairns, G., Angus, K., Hastings, G., Caraher, M., 2013. Systematic reviews of the evidence on the nature, extent and effects of food marketing to children. A retrospective summary. Appetite 62, 209-215. https://doi.org/10.1016/j.appet.2012.04.017

Cardoso, A.P., Mirione, E., Ernesto, M., Massaza, F., Cliff, J., Rezaul Haque, M., Bradbury, J.H., 2005. Processing of cassava roots to remove cyanogens. Journal of Food Composition and Analysis 18, 451-460. https://doi.org/10.1016/j.jfca.2004.04.002

Carletto, C., Zezza, A., Banerjee, R., 2013. Towards better measurement of household food security: Harmonizing indicators and the role of household surveys. Global Food Security 2, 30-40. https://doi.org/10.1016/j.gfs.2012.11.006

Chamberlain, J.L., Cunningham, A.B., Nasi, R., 2004. Diversity in forest management: nontimber forest products and bush meat. Renewable Resources Journal 22, 11-19.

Chipungu, F.P., Ambali, A.J.D., Kalenga Saka, J.D., Mahungu, N.M., Mkumbira, J., 2012. Sweetpotato indigenous knowledge and adaptation to climate change in Malawi. Acta Horticulturae 938, 467-473. https:// doi.org/10.17660/ActaHortic.2012.938.61

Chopra, M., Galbraith, S., Darnton-Hill, I., 2002. A global response to a global problem: the epidemic of overnutrition. Bulletin of the World Health Organization 80, 952-958. 
Choudhury, N., Ahmed, S.M., 2011. Maternal care practices among the ultra poor households in rural Bangladesh: a qualitative exploratory study. BMC pregnancy and childbirth 11, 15. https://doi.org/10.1186/1471-2393-11-15

Chowdhury, A.M., Helman, C., Greenhalgh, T., 2000. Food beliefs and practices among British Bangladeshis with diabetes: Implications for health education. Anthropology \& Medicine 7, 209-226. https://doi.org/10.1080/713650589

Cinner, J.E., 2007. The role of taboos in conserving coastal resources in Madagascar. Traditional Marine Resource Management and Knowledge Information Bulletin 22, 15-23.

Clawson, D.L., 1985. Harvest Security and Intraspecific Diversity in Traditional Tropical Agriculture. Econ Bot 39, 56-67. https://doi.org/10.1007/BF02861175

Coates, J., 2013. Build it back better: Deconstructing food security for improved measurement and action. Global Food Security 2, 188-194. https://doi.org/10.1016/j.gfs.2013.05.002

Coates, J., Frongillo, E.A., Rogers, B.L., Webb, P., Wilde, P.E., Houser, R., 2006. Commonalities in the experience of household food insecurity across cultures: what are measures missing? The Journal of nutrition 136, 1438S-1448S.

Cohen, D.A., 2008. Obesity and the Built Environment: Changes in Environmental Cues Cause Energy Imbalances. Int J Obes (Lond) 32, S137-S142. https://doi.org/10.1038/ijo.2008.250

Colding, J., Folke, C., 2001. Social Taboos: "Invisible" Systems of Local Resource Management and Biological Conservation. Ecological Applications 11, 584. https://doi.org/10.2307/3060911

Colen, L., Swinnen, J., 2016. Economic Growth, Globalisation and Beer Consumption. J Agric Econ 67, 186-207. https://doi.org/10.1111/1477-9552.12128

Cornwall, A., 2003. Whose Voices? Whose Choices? Reflections on Gender and Participatory Development. World Development 31, 1325-1342. https://doi.org/10.1016/S0305750X(03)00086-X

Cumbana, A., Mirione, E., Cliff, J., Bradbury, J.H., 2007. Reduction of cyanide content of cassava flour in Mozambique by the wetting method. Food Chemistry 101, 894-897. https:// doi.org/10.1016/j.foodchem.2006.02.062

Curtis, K., McCluskey, J., Wahl, T., 2004. Consumer acceptance of genetically modified food products in the developing world. AgBioForum 7, 70-75.

D’Andrade, R.G., Strauss, C., 1992. Human Motives and Cultural Models. Cambridge University Press.

Deconinck, K., \& Swinnen, J. (2015). Peer effects and the rise of beer in Russia. Food Policy, 51, 83-96.

De Groote, H., Kimenju, S.C., 2008. Comparing consumer preferences for color and nutritional quality in maize: Application of a semi-double-bound logistic model on urban consumers in Kenya. Food Policy 33, 362-370. https://doi.org/10.1016/j.foodpol.2008.02.005

Deitchler, M., Ballard, T., Swindale, A., Coates, J., 2010. Validation of a measure of household hunger for cross-cultural use.

Denney, L., Mallet, R., Jalloh, R., 2014. Understanding malnutrition and health choices at the community level in Sierra Leone (Researching livelihoods and services affected by conflict No. Report 4), Secure Livelihoods Research Consortium. Overseas Development Institute, United Kingdom.

Dietler, M., Hayden, B., 2010. Feasts: archaelogical and ethnographic perspectives on food, politics and power. University of Alabama Press.

Dixon, H.G., Scully, M.L., Wakefield, M.A., White, V.M., Crawford, D.A., 2007. The effects of television advertisements for junk food versus nutritious food on children's food attitudes and preferences. Social Science \& Medicine 65, 1311-1323.

https://doi.org/10.1016/j.socscimed.2007.05.011 
Dow, J.W., 2007. A scientific definition of religion [WWW Document]. Anpere: Anthropological Perspectives on Religion. URL http://www.anpere.net/2007/2.pdf (accessed 6.13.17).

Dufour, D.L., 1994. Cassava in Amazonia: lessons in utilization and safety from native peoples. Acta Horticulturae 375, 175-182. https://doi.org/10.17660/ActaHortic.1994.375.15

Englberger, L., 2012. Revisiting the vitamin A fiasco: going local in Micronesia, in: Burlingame, B., Dernini, S. (Eds.), Sustainable Diets and Biodiversity. FAO, Rome.

Englberger, L., Marks, G.C., Fitzgerald, M.H., 2003. Insights on food and nutrition in the Federated States of Micronesia: a review of the literature. Public Health Nutrition 6. https://doi.org/10.1079/PHN2002364

Engle, P.L., Nieves, I., 1993. Intra-household food distribution among Guatemalan families in a supplementary feeding program: Behavior patterns. Social Science \& Medicine 36, 16051612. https://doi.org/10.1016/0277-9536(93)90349-9

Evans, D., 2011. Beyond the Throwaway Society: Ordinary Domestic Practice and a Sociological Approach to Household Food Waste. Sociology 0038038511416150. https://doi.org/10.1177/0038038511416150

Evans, D., Campbell, H., Murcott, A., 2012. A brief pre-history of food waste and the social sciences. Sociol Rev 60, 5-26. https://doi.org/10.1111/1467-954X.12035

Fandohan, P., Zoumenou, D., Hounhouigan, D.J., Marasas, W.F.O., Wingfield, M.J., Hell, K., 2005. Fate of aflatoxins and fumonisins during the processing of maize into food products in Benin. International Journal of Food Microbiology 98, 249-259. https://doi.org/10.1016/j.ijfoodmicro.2004.07.007

FAO, 2009. Declaration of the World Summit on Food Security., WSFS 2009/2. Rome.

FAO, 2002. The State of Food Insecurity in the World 2001. Rome.

FAO, 1996. Declaration on world food security. World Food Summit, FAO, Rome.

Feeley-Harnik, G., 1995. Religion and Food: An Anthropological Perspective. Journal of the American Academy of Religion 63, 565-582.

Fessler, D.M., Navarrete, C.D., 2003. Meat is good to taboo: Dietary proscriptions as a product of the interaction of psychological mechanisms and social processes. Journal of Cognition and Culture 3, 1-40. https://doi.org/10.1163/156853703321598563

Fieldhouse, P., 1995. Food and nutrition: customs and culture. Chapman \& Hall, London.

Finucane, M.L., Holup, J.L., 2005. Psychosocial and cultural factors affecting the perceived risk of genetically modified food: an overview of the literature. Social Science \& Medicine 60, 1603-1612. https://doi.org/10.1016/j.socscimed.2004.08.007

Flynn, K.J., Fitzgibbon, M., 1998. Body images and obesity risk among Black females: A review of the literature. ann. behav. med. 20,13-24. https://doi.org/10.1007/BF02893804

Fouts, H.N., Brookshire, R.A., 2009. Who feeds children? A child's-eye-view of caregiver feeding patterns among the Aka foragers in Congo. Social science \& medicine 69, 285-292. https://doi.org/10.1016/j.socscimed.2009.05.016

Fryberg, S.A., Markus, H.R., 2007. Cultural models of education in American Indian, Asian American and European American contexts. Soc Psychol Educ 10, 213-246. https://doi.org/10.1007/s11218-007-9017-z

Gabrysch, S., Campbell, O.M., 2009. Still too far to walk: Literature review of the determinants of delivery service use. BMC Pregnancy Childbirth 9, 34. https://doi.org/10.1186/14712393-9-34

Geçkil, E., Şahin, T., Ege, E., 2009. Traditional postpartum practices of women and infants and the factors influencing such practices in South Eastern Turkey. Midwifery 25, 62-71. https://doi.org/10.1016/j.midw.2006.12.007

Geertz, C., 1993. Religion as a cultural system, in: The Interpretation of Cultures: Selected Essays. Fontana Press, pp. 87-125.

Gershman, B., 2016a. Long-Run Development and the New Cultural Economics, Working Paper. American University. 
Gershman, B., 2016b. Witchcraft beliefs and the erosion of social capital: Evidence from SubSaharan Africa and beyond. Journal of Development Economics 120, 182-208. https://doi.org/10.1016/j.jdeveco.2015.11.005

Gershman, B., 2015. The economic origins of the evil eye belief. Journal of Economic Behavior \& Organization 110,119-144. https://doi.org/10.1016/j.jebo.2014.12.002

Gilbert, P.A., Khokhar, S., 2008. Changing dietary habits of ethnic groups in Europe and implications for health. Nutrition Reviews 66, 203-215. https://doi.org/10.1111/j.17534887.2008.00025.x

Gittelsohn, J., Haberle, H., Vastine, A.E., Dyckman, W., Palafox, N.A., 2003. Macro-and microlevel processes affect food choice and nutritional status in the Republic of the Marshall Islands. The Journal of nutrition 133, 310S-313S.

Gittelsohn, J., Thapa, M., Landman, L.T., 1997. Cultural factors, caloric intake and micronutrient sufficiency in rural Nepali households. Social science \& medicine 44, 1739-1749. https://doi.org/10.1016/S0277-9536(96)00375-9

Godfray, H.C.J., Beddington, J.R., Crute, I.R., Haddad, L., Lawrence, D., Muir, J.F., Pretty, J., Robinson, S., Thomas, S.M., Toulmin, C., 2010. Food security: the challenge of feeding 9 billion people. Science 327, 812-818. https://doi.org/10.1126/science.1185383

Golden, C.D., Comaroff, J., 2015a. The human health and conservation relevance of food taboos in northeastern Madagascar. Ecology and Society 20. https://doi.org/10.5751/ES-07590200242

Golden, C.D., Comaroff, J., 2015b. Effects of social change on wildlife consumption taboos in northeastern Madagascar. Ecology and Society 20. https://doi.org/10.5751/ES-07589200241

Goldman, N., Pebley, A.R., Gragnolati, M., 2002. Choices about treatment for ARI and diarrhea in rural Guatemala. Social Science \& Medicine 55, 1693-1712. https://doi.org/10.1016/S0277-9536(01)00260-X

Gómez-Baggethun, E., Corbera, E., Reyes-García, V., 2013. Traditional Ecological Knowledge and Global Environmental Change: Research findings and policy implications. Ecology and Society 18. https://doi.org/10.5751/ES-06288-180472

Gómez-Baggethun, E., Mingorria, S., Reyes-García, V., Calvet, L., Montes, C., 2010. Traditional ecological knowledge trends in the transition to a market economy: empirical study in the Doñana natural areas. Conservation Biology 24, 721-729. https://doi.org/10.1111/j.1523-1739.2009.01401.x

Gorodnichenko, Y., Roland, G., 2010. Culture, Institutions and the Wealth of Nations. Review of Economics and Statistics. https://doi.org/10.1162/REST_a_00599

Grabe, S., Ward, L.M., Hyde, J.S., 2008. The role of the media in body image concerns among women: a meta-analysis of experimental and correlational studies. Psychological bulletin 134, 460. https://doi.org/10.1037/0033-2909.134.3.460

Greenberg, J.B., 1981. Santiago's sword: Chatino peasant religion and economics. University of California Press, Berkeley.

Grivetti, L.E., Ogle, B.M., 2000. Value of traditional foods in meeting macro- and micronutrient needs: the wild plant connection. Nutrition Research Reviews 13, 31-46. https://doi.org/10.1079/095442200108728990

Guerrero, L., Guàrdia, M.D., Xicola, J., Verbeke, W., Vanhonacker, F., Zakowska-Biemans, S., Sajdakowska, M., Sulmont-Rossé, C., Issanchou, S., Contel, M., Scalvedi, M.L., Granli, B.S., Hersleth, M., 2009. Consumer-driven definition of traditional food products and innovation in traditional foods. A qualitative cross-cultural study. Appetite 52, 345-354. https://doi.org/10.1016/j.appet.2008.11.008

Guiso, L., Sapienza, P., Zingales, L., 2006. Does Culture Affect Economic Outcomes? The Journal of Economic Perspectives 20, 23-48. https://doi.org/10.1257/jep.20.2.23 
Haddad, L.J., Peña, C., Nishida, C., Quisumbing, A.R., Slack, A., 1996. Food security and nutrition implications of intrahousehold bias: a review of the literature (No. 19). International Food Policy Research Institute (IFPRI).

Hadley, C., Zodhiates, A., Sellen, D.W., 2007. Acculturation, economics and food insecurity among refugees resettled in the USA: a case study of West African refugees. Public Health Nutrition 10, 405-412. https://doi.org/10.1017/S1368980007222943

Hammoud, M.M., White, C.B., Fetters, M.D., 2005. Opening cultural doors: Providing culturally sensitive healthcare to Arab American and American Muslim patients. American Journal of Obstetrics and Gynecology 193, 1307-1311. https://doi.org/10.1016/j.ajog.2005.06.065

Harris, J.L., Pomeranz, J.L., Lobstein, T., Brownell, K.D., 2009. A Crisis in the Marketplace: How Food Marketing Contributes to Childhood Obesity and What Can Be Done. Annual Review of Public Health 30, 211-225. https://doi.org/10.1146/annurev.publhealth.031308.100304

Harris-Fry, H., Shrestha, N., Costello, A., Saville, N.M., 2017. Determinants of intra-household food allocation between adults in South Asia - a systematic review. Int J Equity Health 16. https://doi.org/10.1186/s12939-017-0603-1

Hartini, T.N.S., Padmawati, R.S., Lindholm, L., Surjono, A., Winkvist, A., 2005. The importance of eating rice: changing food habits among pregnant Indonesian women during the economic crisis. Social Science \& Medicine 61, 199-210. https://doi.org/10.1016/j.socscimed.2004.11.043

Hawkes, C., 2006. Uneven dietary development: linking the policies and processes of globalization with the nutrition transition, obesity and diet-related chronic diseases. Globalization and Health 2, 4. https://doi.org/10.1186/1744-8603-2-4

Headey, D., Ecker, O., 2013. Rethinking the measurement of food security: from first principles to best practice. Food Security 5, 327-343. https://doi.org/10.1007/s12571-013-0253-0

Helman, C.G., 2007. Culture, health and illness. CRC Press.

Henrich, J., McElreath, R., 2003. The evolution of cultural evolution. Evol. Anthropol. 12, 123135. https://doi.org/10.1002/evan.10110

Higgs, E.S., Goldberg, A.B., Labrique, A.B., Cook, S.H., Schmid, C., Cole, C.F., Obregón, R.A., 2014. Understanding the Role of mHealth and Other Media Interventions for Behavior Change to Enhance Child Survival and Development in Low- and Middle-Income Countries: An Evidence Review. Journal of Health Communication 19, 164-189. https://doi.org/10.1080/10810730.2014.929763

Homsy, J., King, R., Balaba, D., Kabatesi, D., 2004. Traditional health practitioners are key to scaling up comprehensive care for HIV/AIDS in sub-Saharan Africa: AIDS 18, 1723 1725. https://doi.org/10.1097/01.aids.0000131380.30479.16

Hotz, C., Gibson, R.S., 2007. Traditional food-processing and preparation practices to enhance the bioavailability of micronutrients in plant-based diets. The Journal of nutrition 137 , 1097-1100.

Huss-Ashmore, R., Johnston, S., 1994. Wild plants as Cultural Adaptations to Food Stress, in: Eating on the Wild Side: The Pharmacologic, Ecologic and Social Implications of Using Noncultigens. University of Arizona Press, pp. 62-84.

Huynen, M.M., Martens, P., Hilderink, H.B., 2005. The health impacts of globalisation: a conceptual framework. Globalization and health 1, 14. https://doi.org/10.1186/17448603-1-14

Hwang, J.-H., Lee, K.-G., 2006. Reduction of aflatoxin B1 contamination in wheat by various cooking treatments. Food Chemistry 98, 71-75. https://doi.org/10.1016/j.foodchem.2005.04.038

Iannaccone, L.R., 1998. Introduction to the Economics of Religion. Journal of economic literature 1465-1495. 
Inglehart, R.F., 2016. Modernization, existential security and cultural change: Reshaping human motivations and society, in: Gelfand, M., Chiu, C., Hong, Y. (Eds.), Advances in Culture and Psychology. Oxford University Press, New York.

Isildak, Ö., Turkekul, I., Elmastas, M., Tuzen, M., 2004. Analysis of heavy metals in some wildgrown edible mushrooms from the middle black sea region, Turkey. Food Chemistry 86, 547-552. https://doi.org/10.1016/j.foodchem.2003.09.007

Iyer, S., 2016. The New Economics of Religion. Journal of Economic Literature 54, 395-441. https://doi.org/10.1257/jel.54.2.395

Jaenicke, H., Höschle-Zeledon, I., 2006. Strategic Framework for Underutilized Plant Species Research and Development: With Special Reference to Asia and the Pacific, and to SubSaharan Africa. International Centre for Underutilised Crops, Colombo, Sri Lanka and Global Facilitation Unit for Underutilized Species, Rome.

Jamal, A., 1998. Food consumption among ethnic minorities: the case of British-Pakistanis in Bradford, UK. British Food Journal 100, 221-227. https://doi.org/10.1108/00070709810221436

Johns, T., Sthapit, B.R., 2004. Biocultural Diversity in the Sustainability of Developing-Country Food Systems. Food Nutr Bull 25, 143-155. https://doi.org/10.1177/156482650402500207

Jones, J.P.G., Andriamarovololona, M.M., Hockley, N., 2008. The Importance of Taboos and Social Norms to Conservation in Madagascar. Conservation Biology 22, 976-986. https://doi.org/10.1111/j.1523-1739.2008.00970.x

Just, D.R., Heiman, A., Zilberman, D., 2007. The interaction of religion and family members' influence on food decisions. Food Quality and Preference 18, 786-794. https://doi.org/10.1016/j.foodqual.2007.01.008

Kaewsarn, P., Moyle, W., Creedy, D., 2003. Traditional postpartum practices among Thai women. Journal of Advanced Nursing 41, 358-366. https://doi.org/10.1046/j.13652648.2003.02534.x

Kaufmann, J.C., Tsirahamba, S., others, 2006. Forests and thorns: conditions of change affecting Mahafale pastoralists in southwestern Madagascar. Conservation and Society 4, 231.

Kayombo, E.J., Uiso, F.C., Mbwambo, Z.H., Mahunnah, R.L., Moshi, M.J., Mgonda, Y.H., 2007. Experience of initiating collaboration of traditional healers in managing HIV and AIDS in Tanzania. Journal of Ethnobiology and Ethnomedicine 3, 6. https://doi.org/10.1186/1746-4269-3-6

Kearney, J., 2010. Food consumption trends and drivers. Philosophical transactions of the royal society B: biological sciences 365, 2793-2807. https://doi.org/10.1098/rstb.2010.0149

Keats, S., Wiggins, S., 2014. Future diets: Implications for agriculture and food prices, ODI Report. Overseas Development Institute.

Keding, G.B., Schneider, K., Jordan, I., 2013. Production and processing of foods as core aspects of nutrition-sensitive agriculture and sustainable diets. Food Security 5, 825-846. https://doi.org/10.1007/s12571-013-0312-6

Kelly, B., Halford, J.C.G., Boyland, E.J., Chapman, K., Bautista-Castaño, I., Berg, C., Caroli, M., Cook, B., Coutinho, J.G., Effertz, T., Grammatikaki, E., Keller, K., Leung, R., Manios, Y., Monteiro, R., Pedley, C., Prell, H., Raine, K., Recine, E., Serra-Majem, L., Singh, S., Summerbell, C., 2010. Television Food Advertising to Children: A Global Perspective. Am J Public Health 100, 1730-1736. https://doi.org/10.2105/AJPH.2009.179267

Kim-Godwin, Y.S., 2003. Postpartum beliefs and practices among non-Western cultures. MCN: The American Journal of Maternal/Child Nursing 28, 74-78.

King, M., Smith, A., Gracey, M., 2009. Indigenous health part 2: the underlying causes of the health gap. The Lancet 374, 76-85. https://doi.org/10.1016/S0140-6736(09)60827-8 
King, R., 2000. Collaboration with traditional healers in HIV/AIDS prevention and care in subSaharan Africa: a literature review. Joint United Nations Programme on HIV/AIDS. Volume UNAIDS Best Practice Collection., Geneva, Switzerland.

Kittler, P., Sucher, K., Nelms, M., 2011. Food and culture. Cengage Learning.

Klayraung, S., Viernstein, H., Sirithunyalug, J., Okonogi, S., 2008. Probiotic Properties of Lactobacilli Isolated from Thai Traditional Food. Scientia Pharmaceutica 76, 485-503. https://doi.org/10.3797/scipharm.0806-11

Koenig, H., King, D., Carson, V.B., 2012. Handbook of Religion and Health. Oxford University Press.

Kohnert, D., 2007. On the Renaissance of African Modes of Thought - The Example of the Belief in Magic and Witchcraft, in: Schmidt, B. (Ed.), Witchcraft in Modern Africa: Witches, Witch-Hunts and Magical Imaginaries, Veröffentlichungen Des Arbeitskreises Für Historische Hexen- Und Kriminalitätsforschung in Norddeutschland. Verlag Dokumentation \& Buch (DOBU), Hamburg, pp. 39-61.

Korda, H., Itani, Z., 2013. Harnessing Social Media for Health Promotion and Behavior Change. Health Promot Pract 14, 15-23. https://doi.org/10.1177/1524839911405850

Kraft, J.M., Wilkins, K.G., Morales, G.J., Widyono, M., Middlestadt, S.E., 2014. An Evidence Review of Gender-Integrated Interventions in Reproductive and Maternal-Child Health. Journal of Health Communication 19, 122-141. https://doi.org/10.1080/10810730.2014.918216

Kretchmer, S.B., 2004. Advertainment. Journal of Promotion Management 10, 37-54. https://doi.org/10.1300/J057v10n01_04

Kreuter, M.W., Haughton, L.T., 2006. Integrating Culture Into Health Information for African American Women. American Behavioral Scientist 49, 794-811. https://doi.org/10.1177/0002764205283801

Kuhnlein, H., Erasmus, B., Creed-Kanashiro, H., Englberger, L., Okeke, C., Turner, N., Allen, L., Bhattacharjee, L., 2006a. Indigenous peoples' food systems for health: finding interventions that work. Public Health Nutrition 9, 1013. https://doi.org/10.1017/PHN2006987

Kuhnlein, H., Erasmus, B., Spigelski, D., Burlingame, B. (Eds.), 2013. Indigenous peoples’ food systems and well-being: interventions and policies for healthy communities. Food and Agriculture Organization, Rome.

Kuhnlein, H., Smitasiri, S., Yesudas, S., Bhattacharjee, L., Dan, L., Ahmed, S., 2006b. Documenting traditional food systems of indigenous peoples: international case studies. Centre for Indigenous Peoples' Nutrition and Environment, McGill University, SainteAnne-de-Bellevue, Quebec.

Kuhnlein, H.V., 2004. Karat, Pulque, and Gac: Three Shining Stars in the Traditional Food Galaxy. Nutrition Reviews 62, 439-442. https://doi.org/10.1111/j.17534887.2004.tb00015.x

Kuhnlein, H.V., Erasmus, B., Spigelski, D. (Eds.), 2009. Indigenous peoples' food systems: the many dimensions of culture, diversity and environment for nutrition and health, Reprinted. ed. Food and Agriculture Organization, Rome.

Kumar, B.M., Nair, P.K.R., 2004. The enigma of tropical homegardens, in: Nair, P.K.R., Rao, M.R., Buck, L.E. (Eds.), New Vistas in Agroforestry, Advances in Agroforestry. Springer Netherlands, pp. 135-152. https://doi.org/10.1007/978-94-017-2424-1_10

Larsen, J.C., 2006. Risk assessment of chemicals in European traditional foods. Trends in Food Science \& Technology 17, 471-481. https://doi.org/10.1016/j.tifs.2006.04.007

Laway, B.A., Ashraf, H., 2015. Basic rules of Ramadan: A medico-religious perspective. The Journal of the Pakistan Medical Association 65, S14-7. 
Lawrence, W., Barker, M., 2009. A review of factors affecting the food choices of disadvantaged women. Proceedings of the Nutrition Society 68, 189-194. https://doi.org/10.1017/S0029665109001013

Lee, D.T.S., Ngai, I.S.L., Ng, M.M.T., Lok, I.H., Yip, A.S.K., Chung, T.K.H., 2009. Antenatal taboos among Chinese women in Hong Kong. Midwifery 25, 104-113. https://doi.org/10.1016/j.midw.2007.01.008

Lee, J.W., Morton, K.R., Walters, J., Bellinger, D.L., Butler, T.L., Wilson, C., Walsh, E., Ellison, C.G., McKenzie, M.M., Fraser, G.E., 2009. Cohort Profile: The biopsychosocial religion and health study (BRHS). Int. J. Epidemiol. 38, 1470-1478. https://doi.org/10.1093/ije/dyn244

Leistner, E., 2014. Witchcraft and African development. African Security Review 23, 53-77. https://doi.org/10.1080/10246029.2013.875048

LeMay-Boucher, P., Noret, J., Somville, V., 2013. Facing Misfortune: Expenditures on MagicoReligious Powers for Cure and Protection in Benin. Journal of African Economies 22, 300-322. https://doi.org/10.1093/jae/ ejs032

Lilette, V., 2006. Mixed Results: Conservation of the Marine Turtle and the Red-Tailed Tropicbird by Vezo Semi-Nomadic Fishers. Conservation and Society 4, 262.

Liu, S., Han, Y., Zhou, Z., 2011. Lactic acid bacteria in traditional fermented Chinese foods. Food Research International 44, 643-651. https://doi.org/10.1016/j.foodres.2010.12.034

Lori, J.R., Boyle, J.S., 2011. Cultural Childbirth Practices, Beliefs, and Traditions in Postconflict Liberia. Health Care for Women International 32, 454-473. https://doi.org/10.1080/07399332.2011.555831

Lovato, C., Watts, A., Stead, L.F., 2011. Impact of tobacco advertising and promotion on increasing adolescent smoking behaviours. The Cochrane Library. https://doi.org/10.1002/14651858.CD003439.pub2

Lyimo, M.H., Nyagwegwe, S., Mnkeni, A.P., 1991. Investigations on the effect of traditional food processing, preservation and storage methods on vegetable nutrients: a case study in Tanzania. Plant Foods Hum Nutr 41, 53-57. https://doi.org/10.1007/BF02196382

Maarleveld, M., Dangbégnon, C., 1999. Managing natural resources: A social learning perspective. Agriculture and human values 16, 267-280. https://doi.org/10.1023/A:1007559903438

Mahajan, A.P., Sayles, J.N., Patel, V.A., Remien, R.H., Ortiz, D., Szekeres, G., Coates, T.J., 2008. Stigma in the HIV/AIDS epidemic: A review of the literature and recommendations for the way forward. AIDS 22, S67-S79. https://doi.org/10.1097/01.aids.0000327438.13291.62

Makokha, A., Oniang'o, R., Njoroge, S., Kamar, O., 2002. Effect of traditional fermentation and malting on phytic acid and mineral availability from sorghum (Sorghum bicolor) and finger millet (Eleusine coracana) grain varieties grown in Kenya. Food Nutr Bull 23, $241-$ 245.

Matson-Koffman, D.M., Brownstein, J.N., Neiner, J.A., Greaney, M.L., 2005. A Site-Specific Literature Review of Policy and Environmental Interventions That Promote Physical Activity and Nutrition for Cardiovascular Health: What Works? American Journal of Health Promotion 19, 167-193. https://doi.org/10.4278/0890-1171-19.3.167

Matsumoto, D., Juang, L., 2013. Culture and psychology, Fifth Edition. ed. Wadsworth: Cengage Learning.

Mazzocchi, F., 2006. Western science and traditional knowledge. EMBO reports 7, 463-466. https://doi.org/10.1038/sj.embor.7400693

McCluskey, J.J., Swinnen, J.F., 2004. Political economy of the media and consumer perceptions of biotechnology. American Journal of Agricultural Economics 86, 1230-1237. https://doi.org/10.1111/j.0002-9092.2004.00670.x 
McLaughlin, L.A., Braun, K.L., 1998. Asian and Pacific Islander Cultural Values: Considerations for Health Care Decision Making. Health Social Work 23, 116-126.

https://doi.org/10.1093/hsw/23.2.116

McLean, N., Griffin, S., Toney, K., Hardeman, W., 2003. Family involvement in weight control, weight maintenance and weight-loss interventions: a systematic review of randomised trials. Int J Obes Relat Metab Disord 27, 987-1005. https://doi.org/10.1038/sj.ijo.0802383

Meenakshi, J.V., Banerji, A., Manyong, V., Tomlins, K., Mittal, N., Hamukwala, P., 2012. Using a discrete choice experiment to elicit the demand for a nutritious food: Willingness-to-pay for orange maize in rural Zambia. Journal of Health Economics 31, 62-71. https://doi.org/10.1016/j.jhealeco.2012.01.002

Mesoudi, A., 2011. Cultural Evolution: How Darwinian Theory Can Explain Human Culture and Synthesize the Social Sciences. University of Chicago Press, Chicago and London.

Meyer-Rochow, V., 2009. Food taboos: their origins and purposes. Journal of Ethnobiology and Ethnomedicine 5, 18. https://doi.org/10.1186/1746-4269-5-18

Micklesfield, L.K., Lambert, E.V., Hume, D.J., Chantler, S., Pienaar, P.R., Dickie, K., Puoane, T., Goedecke, J.H., 2013. Socio-cultural, environmental and behavioural determinants of obesity in black South African women. Cardiovascular Journal of Africa 24, 369-75. https://doi.org/10.5830/CVJA-2013-069

Midhet, F., Becker, S., 2010. Impact of community-based interventions on maternal and neonatal health indicators: Results from a community randomized trial in rural Balochistan, Pakistan. Reproductive Health 7, 30. https://doi.org/10.1186/1742-4755-7-30

Milburn, M.P., 2004. Indigenous Nutrition: Using Traditional Food Knowledge to Solve Contemporary Health Problems. The American Indian Quarterly 28, 411-434. https://doi.org/10.1353/aiq.2004.0104

Mills, E., Singh, S., Wilson, K., Peters, E., Onia, R., Kanfer, I., 2006. The challenges of involving traditional healers in HIV/AIDS care. Int J STD AIDS 17, 360-363. https://doi.org/10.1258/095646206777323382

Mintz, S.W., Du Bois, C.M., 2002. The Anthropology of Food and Eating. Annual Review of Anthropology 31, 99-119. https://doi.org/10.1146/annurev.anthro.32.032702.131011

Monteiro, C.A., 2009. Nutrition and health. The issue is not food, nor nutrients, so much as processing. Public Health Nutrition 12, 729-731. https://doi.org/10.1017/S1368980009005291

Monteiro, C.A., Moubarac, J.-C., Cannon, G., Ng, S.W., Popkin, B., 2013. Ultra-processed products are becoming dominant in the global food system. Obes Rev 14, 21-28. https://doi.org/10.1111/obr.12107

Moorhead, S.A., Hazlett, D.E., Harrison, L., Carroll, J.K., Irwin, A., Hoving, C., 2013. A New Dimension of Health Care: Systematic Review of the Uses, Benefits, and Limitations of Social Media for Health Communication. Journal of Medical Internet Research 15, e85. https://doi.org/10.2196/jmir.1933

Morris, M.D., Popper, S.T., Rodwell, T.C., Brodine, S.K., Brouwer, K.C., 2009. Healthcare Barriers of Refugees Post-resettlement. J Community Health 34, 529. https://doi.org/10.1007/s10900-009-9175-3

Moss, N.E., 2002. Gender equity and socioeconomic inequality: a framework for the patterning of women's health. Social Science \& Medicine, Social \& Economic Patterning of Women"s Health in a Changing World 54, 649-661. https://doi.org/10.1016/S02779536(01)00115-0

Muhammad, S., Shah, M.T., Khan, S., 2011. Heavy metal concentrations in soil and wild plants growing around $\mathrm{Pb}-\mathrm{Zn}$ sulfide terrain in the Kohistan region, northern Pakistan. Microchemical Journal 99, 67-75. https://doi.org/10.1016/j.microc.2011.03.012 
Mullany, B.C., Becker, S., Hindin, M.J., 2007. The impact of including husbands in antenatal health education services on maternal health practices in urban Nepal: results from a randomized controlled trial. Health Educ. Res. 22, 166-176. https://doi.org/10.1093/her/cyl060

Mumtaz, Z., Salway, S., 2005. "I never go anywhere": extricating the links between women's mobility and uptake of reproductive health services in Pakistan. Social Science \& Medicine 60, 1751-1765. https://doi.org/10.1016/j.socscimed.2004.08.019

Murphy, P.A., Hendrich, S., Landgren, C., Bryant, C.M., 2006. Food Mycotoxins: An Update. Journal of Food Science 71, R51-R65. https://doi.org/10.1111/j.17503841.2006.00052.x

Nabulo, G., Young, S.D., Black, C.R., 2010. Assessing risk to human health from tropical leafy vegetables grown on contaminated urban soils. Science of The Total Environment 408, 5338-5351. https://doi.org/10.1016/j.scitotenv.2010.06.034

Nestle, M., Wing, R., Birch, L., DiSogra, L., Drewnowski, A., Middleton, S., Sigman-Grant, M., Sobal, J., Winston, M., Economos, C., 1998. Behavioral and social influences on food choice. Nutrition reviews 56, 50-64. https://doi.org/10.1111/j.17534887.1998.tb01732.x

Nicoll, M.E., 2003. Tenrec ecaudatus, tenrec, tandraka, trandraka, in: Goodman, S.M., Benstead, J.P. (Eds.), The Natural History of Madagascar. University of Chicago Press, Chicago.

Nwajiuba, C.A., Okechukwu, O., 2006. Social status, traditional food taboos and food security: A study of Igbo women in Imo State, Nigeria. Journal of Agriculture and Food Sciences 4, 139-146. https://doi.org/10.4314/jafs.v4i2.41601

Obermeyer, C.M., 2000. Pluralism and Pragmatism: Knowledge and Practice of Birth in Morocco. Medical Anthropology Quarterly 14, 180-201. https://doi.org/10.1525/maq.2000.14.2.180

Odebiyi, A.I., 1989. Food taboos in maternal and child health: The views of traditional healers in Ile-Ife, Nigeria. Social Science \& Medicine 28, 985-996. https://doi.org/10.1016/02779536(89)90328-6

Olvera, N., Suminski, R., Power, T.G., 2005. Intergenerational Perceptions of Body Image in Hispanics: Role of BMI, Gender, and Acculturation. Obesity Research 13, 1970-1979. https://doi.org/10.1038/oby.2005.242

Palis, F.G., 2006. The role of culture in farmer learning and technology adoption: A case study of farmer field schools among rice farmers in central Luzon, Philippines. Agriculture and Human Values 23, 491-500. https://doi.org/10.1007/s10460-006-9012-6

Pangaribowo, E., Gerber, N., Tillie, P., 2013. Assessing the FNS impacts of technological and institutional innovations and future innovation trends (FoodSecure Deliverable No. 3.2.). LEI Wageningen UR.

Parker, R., Aggleton, P., 2003. HIV and AIDS-related stigma and discrimination: a conceptual framework and implications for action. Social Science \& Medicine 57, 13-24. https://doi.org/10.1016/S0277-9536(02)00304-0

Patrick, H., Nicklas, T.A., 2005. A Review of Family and Social Determinants of Children's Eating Patterns and Diet Quality. Journal of the American College of Nutrition 24, 83 92. https://doi.org/10.1080/07315724.2005.10719448

Penafiel, D., Lachat, C., Espinel, R., Damme, P.V., Kolsteren, P., 2011. A Systematic Review on the Contributions of Edible Plant and Animal Biodiversity to Human Diets. EcoHealth 8, 381-399. https://doi.org/10.1007/s10393-011-0700-3

Pérez-Escamilla, R., Hromi-Fiedler, A., Vega-López, S., Bermúdez-Millán, A., Segura-Pérez, S., 2008. Impact of Peer Nutrition Education on Dietary Behaviors and Health Outcomes among Latinos: A Systematic Literature Review. Journal of Nutrition Education and Behavior 40, 208-225. https://doi.org/10.1016/j.jneb.2008.03.011 
Pieniak, Z., Verbeke, W., Vanhonacker, F., Guerrero, L., Hersleth, M., 2009. Association between traditional food consumption and motives for food choice in six European countries.

Appetite 53, 101-108. https://doi.org/10.1016/j.appet.2009.05.019

Pinstrup-Andersen, P., 2009. Food security: definition and measurement. Food Security 1, 5-7. https://doi.org/10.1007/s12571-008-0002-y

Piperata, B.A., 2008. Forty days and forty nights: A biocultural perspective on postpartum practices in the Amazon. Social Science \& Medicine 67, 1094-1103. https://doi.org/10.1016/j.socscimed.2008.05.031

Pomerleau, J., Lock, K., Knai, C., McKee, M., 2005. Interventions Designed to Increase Adult Fruit and Vegetable Intake Can Be Effective: A Systematic Review of the Literature. J. Nutr. 135, 2486-2495.

Popkin, B.M., Adair, L.S., Ng, S.W., 2012. Global nutrition transition and the pandemic of obesity in developing countries. Nutrition Reviews 70, 3-21. https://doi.org/10.1111/j.1753-4887.2011.00456.x

Postma, J.A., Lynch, J.P., 2012. Complementarity in root architecture for nutrient uptake in ancient maize/bean and maize/bean/squash polycultures. Ann Bot 110, 521-534. https://doi.org/10.1093/aob/mcs082

Pradeep, S.R., Guha, M., 2011. Effect of processing methods on the nutraceutical and antioxidant properties of little millet (Panicum sumatrense) extracts. Food Chemistry 126, 1643-1647. https://doi.org/10.1016/j.foodchem.2010.12.047

Randolph, W., Viswanath, K., 2004. Lessons Learned from Public Health Mass Media Campaigns: Marketing Health in a Crowded Media World. Annual Review of Public Health 25, 419-437. https://doi.org/10.1146/annurev.publhealth.25.101802.123046

Raven, J.H., Chen, Q., Tolhurst, R.J., Garner, P., 2007. Traditional beliefs and practices in the postpartum period in Fujian Province, China: a qualitative study. BMC Pregnancy and Childbirth 7, 8. https://doi.org/10.1186/1471-2393-7-8

Ravindran, S., 1986. Health implications of sex discrimination in childhood: A review paper and an annotated bibliography (No. 86.2), WHO/UNICEF/FHE.

Renzaho, A.M.N., Mellor, D., 2010. Food security measurement in cultural pluralism: Missing the point or conceptual misunderstanding? Nutrition 26, 1-9. https://doi.org/10.1016/j.nut.2009.05.001

Reyes-García, V., Guèze, M., Luz, A.C., Paneque-Gálvez, J., Macía, M.J., Orta-Martínez, M., Pino, J., Rubio-Campillo, X., 2013. Evidence of traditional knowledge loss among a contemporary indigenous society. Evolution and Human Behavior 34, 249-257. https://doi.org/10.1016/j.evolhumbehav.2013.03.002

Richerson, P.J., Christiansen, M.H. (Eds.), 2013. Cultural Evolution: Society, Technology, Language, and Religion. MIT Press.

Risch, S.J., 1981. Insect Herbivore Abundance in Tropical Monocultures and Polycultures: An Experimental Test of Two Hypotheses. Ecology 62, 1325-1340. https://doi.org/10.2307/1937296

Roche, M., Creed-Kanashiro, H., Tuesta, I., Kuhnlein, H., 2008. Traditional food diversity predicts dietary quality for the Awajún in the Peruvian Amazon. Public Health Nutrition 11. https://doi.org/10.1017/S1368980007000560

Roesel, K., Grace, D., Baumann, M.P.O., Fries, R., Clausen, P.H., 2015. Food safety in low income countries, Presented at the 15th expert conference on meat and poultry hygiene, Berlin, Germany, 3-4 March 2015. ILRI, Nairobi, Kenya.

Ronteltap, A., van Trijp, H., Renes, R.-J., Frewer, L., 2007. Consumer acceptance of technologybased food innovations: Lessons for the future of nutrigenomics. Appetite 49, 1-17. https://doi.org/10.1016/j.appet.2007.02.002 
Ruiz-Rodriguez, A., Marín, F.R., Ocaña, A., Soler-Rivas, C., 2008. Effect of domestic processing on bioactive compounds. Phytochem Rev 7, 345-384. https://doi.org/10.1007/s11101007-9073-1

Rutsaert, P., Regan, Á., Pieniak, Z., McConnon, Á., Moss, A., Wall, P., Verbeke, W., 2013. The use of social media in food risk and benefit communication. Trends in Food Science \& Technology 30, 84-91. https://doi.org/10.1016/j.tifs.2012.10.006

Sabaté, J., 2004. Religion, diet and research. British Journal of Nutrition 92, 199. https://doi.org/10.1079/BJN20041229

Santos-Torres, M.I., Vásquez-Garibay, E., 2003. Food taboos among nursing mothers of Mexico. Journal of Health, Population and Nutrition 142-149.

Scott, K., McMahon, S., Yumkella, F., Diaz, T., George, A., 2014. Navigating multiple options and social relationships in plural health systems: a qualitative study exploring healthcare seeking for sick children in Sierra Leone. Health Policy Plan 29, 292-301. https://doi.org/10.1093/heapol/czt016

Sein, K.K., 2013. Beliefs and practices surrounding postpartum period among Myanmar women. Midwifery 29, 1257-1263. https://doi.org/10.1016/j.midw.2012.11.012

Semega-Janneh, I.J., Bøhler, E., Holm, H., Matheson, I., Holmboe-Ottesen, G., 2001. Promoting breastfeeding in rural Gambia: combining traditional and modern knowledge. Health Policy Plan. 16, 199-205. https://doi.org/10.1093/heapol/16.2.199

Sheikh-Mohammed, M., MacIntyre, C.R., Wood, N.J., Leask, J., Isaacs, D., 2006. Barriers to access to health care for newly resettled sub-Saharan refugees in Australia. Medical Journal of Australia, The Medical Journal of Australia 185.

Sho, H., 2001. History and characteristics of Okinawan longevity food. Asia Pacific Journal of Clinical Nutrition 10,159-164. https://doi.org/10.1111/j.1440-6047.2001.00235.x

Shweder, R.A., 2000. Moral maps, “first world” conceits, and the new evangelists, in: Harrison, L.E., Huntington, S.P. (Eds.), Culture Matters: How Values Shape Human Progress. Basic Books, New York, pp. 158-176.

Smedley, B.D., Stith, A.Y., Nelson, A.R. (Eds.), 2002a. Unequal treatment: Confronting racial and ethnic disparities in health care (full printed version). National Academies Press.

Smedley, B.D., Stith, A.Y., Nelson, A.R., others, 2002b. Unequal treatment: Confronting racial and ethnic disparities in health care (full printed version). National Academies Press.

Snyder, L.B., 2007. Health Communication Campaigns and Their Impact on Behavior. Journal of Nutrition Education and Behavior 39, S32-S40. https://doi.org/10.1016/j.jneb.2006.09.004

Snyder, L.B., Hamilton, M.A., Mitchell, E.W., Kiwanuka-Tondo, J., Fleming-Milici, F., Proctor, D., 2004. A Meta-Analysis of the Effect of Mediated Health Communication Campaigns on Behavior Change in the United States. Journal of Health Communication 9, 71-96. https://doi.org/10.1080/10810730490271548

Spector, R.E., 2002. Cultural Diversity in Health and Illness. J Transcult Nurs 13, 197-199. https://doi.org/10.1177/10459602013003007

Spolaore, E., Wacziarg, R., 2013. How Deep Are the Roots of Economic Development? Journal of Economic Literature 51, 1-6. https://doi.org/10.1257/jel.51.2.1

Steinberg, S., 1996. Childbearing research: a transcultural review. Social Sciences \& Medicine 43, 1765-178. https://doi.org/10.1016/S0277-9536(96)00071-8

Stephens, C., Porter, J., Nettleton, C., Willis, R., 2006. Disappearing, displaced, and undervalued: a call to action for Indigenous health worldwide. The Lancet 367, 2019-2028. https://doi.org/10.1016/S0140-6736(06)68892-2

Sternberg, P., Hubley, J., 2004. Evaluating men's involvement as a strategy in sexual and reproductive health promotion. Health Promot. Int. 19, 389-396. https://doi.org/10.1093/heapro/dah312 
Stevens, R., Winter-Nelson, A., 2008. Consumer acceptance of provitamin A-biofortified maize in Maputo, Mozambique. Food Policy 33, 341-351. https://doi.org/10.1016/j.foodpol.2007.12.003

Stifel, D., Fafchamps, M., Minten, B., 2011. Taboos, Agriculture and Poverty. Journal of Development Studies 47, 1455-1481. https://doi.org/10.1080/00220388.2011.561322

Stigter, C.J., Dawei, Z., Onyewotu, L.O.Z., Xurong, M., 2005. Using Traditional Methods and Indigenous Technologies for Coping With Climate Variability. Climatic Change 70, 255271. https://doi.org/10.1007/s10584-005-5949-5

Swami, V., Knight, D., Tovée, M.J., Davies, P., Furnham, A., 2007. Preferences for female body size in Britain and the South Pacific. Body Image 4, 219-223. https://doi.org/10.1016/j.bodyim.2007.01.002

Swinnen, J., Briski, D., 2017. Beeronomics: How Beer Explains the World. Oxford University Press.

Tapsell, L.C., Hemphill, I., Cobiac, L., Patch, C.S., Sullivan, D.R., Fenech, M., Roodenrys, S., Keogh, J.B., Clifton, P.M., Williams, P.G., Fazio, V.A., Inge, K.E., 2006. Health benefits of herbs and spices: the past, the present, the future. The Medical Journal of Australia 185, S4-24.

Taras, V., Rowney, J., Steel, P., 2009. Half a century of measuring culture: Review of approaches, challenges, and limitations based on the analysis of 121 instruments for quantifying culture. Journal of International Management 15, 357-373. https://doi.org/10.1016/j.intman.2008.08.005

Taylor, J.P., Evers, S., McKenna, M., 2005. Determinants of Healthy Eating in Children and Youth. Canadian Journal of Public Health / Revue Canadienne de Santé Publique 96, S20-S26.

Termote, C., Damme, P.V., Djailo, B.D., 2011. Eating from the wild: Turumbu, Mbole and Bali traditional knowledge on non-cultivated edible plants, District Tshopo, DRCongo. Genetic Resources and Crop Evolution 58, 585-618. https://doi.org/10.1007/s10722010-9602-4

Trichopoulou, A., Soukara, S., Vasilopoulou, E., 2007. Traditional foods: a science and society perspective. Trends in Food Science \& Technology, EuroFIR 18, 420-427. https://doi.org/10.1016/j.tifs.2007.03.007

UN, 2015. State of the World's Indigenous Peoples: Indigenous Peoples' Access to Health Services.

UN, 2009. State of the World's Indigenous Peoples. New York.

Vanclay, F., 2004. Social principles for agricultural extension to assist in the promotion of natural resource management. Animal Production Science 44, 213-222. https://doi.org/10.1071/EA02139

Vigani, M., Olper, A., 2015. Patterns and Determinants of GMO Regulations: An Overview of Recent Evidence.

von Braun, J., Thorat, S., 2014. Policy implications of exclusion and resilience, in: Resilience for Food and Nutrition Security. IFPRI.

Wakefield, M., Flay, B., Nichter, M., Giovino, G., 2003. Role of the media in influencing trajectories of youth smoking. Addiction 98, 79-103. https://doi.org/10.1046/j.13600443.98.s1.6.x

Wakefield, M.A., Loken, B., Hornik, R.C., 2010. Use of mass media campaigns to change health behaviour. The Lancet 376, 1261-1271. https://doi.org/10.1016/S0140-6736(10)60809-4

Wardle, J., Cooke, L., 2008. Genetic and environmental determinants of children's food preferences. British Journal of Nutrition 99, S15-S21. https://doi.org/10.1017/S000711450889246X

Watson, J.L., 2006. Golden arches east: McDonald's in East Asia. Stanford University Press, Stanford, California. 
Weisner, T.S., 2000. Culture, childhood, and progress in sub-Saharan Africa, in: Harrison, L.E., Huntington, S.P. (Eds.), Culture Matters: How Values Shape Human Progress. Basic Books, New York, pp. 141-157.

WFP, 2012. Nutrition at the World Food Programme: Programming for Nutrition-Specific Interventions.

WHO, 2013. WHO traditional medicine strategy 2014-2023. World Health Organization, Geneva.

WHO, 2012. Social determinants of health and well-being among young people: health behaviour in school-aged (HBSC) children: international report from the 2009/2010 survey. World Health Organization, Regional Office for Europe, Copenhagen, Denmark.

Wild, C.P., Gong, Y.Y., 2010. Mycotoxins and human disease: a largely ignored global health issue. Carcinogenesis 31, 71-82. https://doi.org/10.1093/carcin/bgp264

Wiley, A.S., 2002. Increasing use of prenatal care in Ladakh (India): the roles of ecological and cultural factors. Social Science \& Medicine 55, 1089-1102. https://doi.org/10.1016/S0277-9536(01)00257-X

Wilk, R. (Ed.), 2006. Fast food/slow food: the cultural economy of the global food system. Altamira Press.

Williams, D.R., Mohammed, S.A., 2009. Discrimination and racial disparities in health: evidence and needed research. J Behav Med 32, 20-47. https://doi.org/10.1007/s10865-008-91850

Winham, D.M., 2009. Culturally tailored foods and CVD prevention. Am J Lifestyle Med 3, 64S68S. https://doi.org/10.1177/1559827609335552

Zhang, A.L., Changli Xue, C., Fong, H.H.S., 2011. Integration of Herbal Medicine into EvidenceBased Clinical Practice: Current Status and Issues, in: Benzie, I.F.F., Wachtel-Galor, S. (Eds.), Herbal Medicine: Biomolecular and Clinical Aspects. CRC Press/Taylor \& Francis, Boca Raton (FL). 


\section{Boxes}

Box 1: The Native American 'three sister' production system Based on the belief that the spirits of the 'three sisters' belonged together, the Six Nations people traditionally planted maize, beans and squash together. Agriculturally, this integrated agro-ecosystem has many advantages (e.g. Altieri, 1999; Postma and Lynch, 2012; Risch, 1981). Maize has high nitrogen requirements, and beans bring atmospheric nitrogen into the soil with the help of symbiotic bacteria. The maize stalks in turn provide structural support to the climbing bean plants. With their large round leaves, squash plants shade the soil and as such help conserve moisture and reduce weeds. Integrated plantings also reduce pest problems.

Source: Milburn (2004) 
Box 2: Strictly enforced taboos for pregnant women in Ghana

In rural Ghana, pregnant women are forbidden to eat various foods including snails, rats, snakes, hot foods and animal lungs. These taboos are seen as instructions from god passed down from generation to generation to safeguard them against evil and diseases. Disobedience is considered blasphemous and believed to lead to anger of the ancestors, which can put the community and the health of mother and child at risk. Pregnant women are therefore continuously reminded about the taboos and those who break them are constantly frowned upon or even excommunicated from the family or community.

Source: Arzoaquoi et al. (2015) 
Box 3: The benefits of 'little millets'

A species of millet (Panicum sumatrense), known as 'little millets' is
one of the oldest food grains known to humans and grows well
in dry zones, producing crops even on very poor soils. These
grains form a traditional staple food for low-income groups in
some South Asian countries (Pradeep and Guha, 2011), where
they are processed into healthy snacks or nourishing flour that
can be mixed with rice flour, offering longer shelf-life. The millets
are rich in vitamins, phenolic acids, calcium and iron and contain
more soluble fibre than rice or wheat. Moreover, the little millets
also have a low glycaemic index, making them attractive health
foods.

Source: Jaenicke and Höschle-Zeledon (2006) 
Box 4: Traditional cassava processing techniques

Cassava naturally contains cyanide in modest quantities. Consumption of large amounts of cassava and derived products may therefore cause cyanide poisoning, leading to symptoms such as vomiting, diarrhoea, and possibly death. In addition, cyanide intake from cassava exacerbates goitre and cretinism in iodine deficient areas, and chronic dietary exposure to cyanide has been associated with diseases such as konzo and Tropical Ataxic Neuropathy. Processing methods to reduce the cyanide content of cassava flour were developed by trial and error hundreds of years ago by indigenous peoples in Amazonia for the preparation of farinha (cassava flour) which involves scraping, grating and roasting of the roots. This elaborate technique has been proven very efficient in reducing cyanogen levels, and there is no evidence of cyanide toxicity associated with cassava use among indigenous peoples in Amazonia. In contrast, heap fermentation and sun drying, commonly used in eastern and southern Africa, do not adequately remove cyanide.

Source: Cardoso et al. (2005) and Dufour (1994) 
Box 5: The conservation value of Malagasy social norms Among central eastern Malagasy communities, strict social norms govern the timing for harvesting and hunting certain species. The 'correct' time for hunting tailless tenrecs (a small mammal somewhat similar to a hedgehog) is for example considered to be April or May, which is after the young have become independent (Nicoll, 2003). Despite the fact that the sanction is social disapproval rather than supernatural retribution, this taboo is strictly observed. Tenrec hunting (as opposed to killing a tenrec found during other activities) only occurs during these months. As such, this taboo contributes to the sustainable exploitation of this species.

Source: Jones et al. (2008) 
Box 6: The importance of gender roles in explaining the impact of 'resguardo' in the Eastern Amazon

'Resguardo' derives from the Portuguese verb 'to protect' (resguardar) and refers to a period of food and work restrictions for women after childbirth. Women throughout several parts of Brazil and other Latin American countries observe the practice. An analysis of dietary intakes during resguardo revealed that resguardo women have lower energy intakes, but not as a result of dietary restrictions. RInstead, the combination of work restrictions and gendered household labour division explains the energy reduction. In particular, resguardo work restrictions prevent women from performing their usual staple food processing and preparation tasks, which reduces the availability of staple foods in the household (as husbands generally do not take over).

Source: Piperata (2008) 
Box 7: Focus on unhealthy foods in television advertising

Analysis of television advertisements on channels most popular with children in 13 countries across 5 continents revealed that in each country, food products were in the top 3 advertised products. For all countries, the majority of food advertisements (67\%) were for foods that are relatively high in undesirable nutrients including fat and sodium. Programmes specifically targeting children contained an even higher proportion of advertisements for these foods $(80 \%$ of food advertisements). Fast-food restaurant meals and chocolate and confectionary in particular were the most frequently advertised food products.

Source: Kelly et al. (2010) 